\title{
Human Dimensions of Urban Blue and Green Infrastructure during a Pandemic. Case Study of Moscow (Russia) and Perth (Australia)
}

\author{
Diana Dushkova ${ }^{1,2, *(\mathbb{D}}$, Maria Ignatieva ${ }^{3}{ }^{\oplus}$, Michael Hughes ${ }^{4}\left(\mathbb{D}\right.$, Anastasia Konstantinova ${ }^{2}{ }^{(}$, \\ Viacheslav Vasenev ${ }^{2,5}$ (i) and Elvira Dovletyarova ${ }^{2}$ (])
}

1 Department of Urban and Environmental Sociology, Helmholtz-Centre for Environmental Research (UFZ), 04318 Leipzig, Germany

2 Agrarian and Technological Institute, Peoples Friendship University of Russia (RUDN), 117198 Moscow, Russia; konstantinova-av@rudn.ru (A.K.); vasenev-vi@rudn.ru (V.V.); dovletyarova-ea@rudn.ru (E.D.)

3 School of Design, The University of Western Australia (UWA), 6009 Perth, Australia; maria.ignatieva@uwa.edu.au

4 Harry Butler Institute, Murdoch University (MU), 6150 Murdoch, Australia; m.hughes@murdoch.edu.au

5 Department of Soil Geography and Landscape, Wageningen University and Research Centre (WUR), 6708 PB Wageningen, The Netherlands

* Correspondence: diana.dushkova@ufz.de; Tel.: +49-176-256-91-753

check for updates

Citation: Dushkova, D.; Ignatieva, M.; Hughes, M.; Konstantinova, A.; Vasenev, V.; Dovletyarova, E. Human Dimensions of Urban Blue and Green Infrastructure during a Pandemic. Case Study of Moscow (Russia) and Perth (Australia). Sustainability 2021, 13, 4148. https://doi.org/10.3390/ su13084148

Academic Editor: Nyuk Hien Wong

Received: 16 March 2021

Accepted: 6 April 2021

Published: 8 April 2021

Publisher's Note: MDPI stays neutral with regard to jurisdictional claims in published maps and institutional affiliations.

Copyright: (c) 2021 by the authors. Licensee MDPI, Basel, Switzerland. This article is an open access article distributed under the terms and conditions of the Creative Commons Attribution (CC BY) license (https:// creativecommons.org/licenses/by/ $4.0 /)$.

\begin{abstract}
Significant challenges of the COVID-19 pandemic highlighted that features of a modern, sustainable and resilient city should not only relate to fulfilling economic and social urban strategies, but also to functional urban design, in particular, related to urban blue and green infrastructure (BGI). Using results from a web-based questionnaire survey conducted May-July 2020 in Moscow (Russia) and Perth (Australia), this paper provides insights regarding citizens' needs for and values of urban BGI as well as their changes during and after the COVID-19 restrictions. Survey data collected during the lockdown period have captured information about people's ability to access green and blue spaces within urban BGI, inequalities in access, feelings, and values as well as needs and perceived pathways of future development of urban natural environment. In both cities, lockdowns limited access of people to green spaces which affected their mental and physical health. Survey results revealed that the quality, functionality, and location of open green spaces illustrated a disparity in distribution, meaning that in many cases several communities from particular neighborhoods suffered from limited access to BGI. Furthermore, in addition to analyzing perceptions and values of urban nature during the COVID-19 pandemic, some suggestions for improvement of urban BGI based on the survey responses are provided.
\end{abstract}

Keywords: urban green space; blue space; blue-green infrastructure; citizen perceptions; green use practices; COVID-19 pandemic; Moscow; Perth

\section{Introduction}

The COVID-19 pandemic and related lockdowns around the world led to a general decline in physical and mental health because of isolation, lack of social interaction, restriction of movement and travel, and dramatic lifestyle changes [1]. The COVID-19 pandemic also demonstrated the importance of having access to green and blue spaces for human health and well-being during pandemics [2-4]. In this paper, urban blue and green infrastructure (BGI) refers to an interconnected network of natural and designed landscape components, including water bodies and green and open spaces at the city scale. BGI includes publicly accessible and private green space, natural green space (remnants of native vegetation which experience different intensities of human intervention and where some or all endemic ecosystem processes are affected) as well as specifically designed 
and managed green space (e.g., parks, gardens, lawns, street plantings, green roofs) and blue space (retention and detention ponds, re-naturalized and de-culverted rivers, swales and "bioswales", or rain gardens) [5-8]. The theme of positive benefits of urban BGI and associated urban green and blue spaces for human physical (e.g., through the opportunity for physical activity, recreation) and mental (e.g., ability to relax, stress reduction, spiritual enrichment, cognitive development, reflection, aesthetic experiences) health of urban dwellers prior to the pandemic is also thoroughly studied [7,9-14]. Urban green and blue spaces also contribute to a sense of place as well as fostering social cohesion and stewardship. These factors are essential for quality of life and regional identity [15-17].

The COVID-19 circumstances, when billions of people over the globe were locked down with limited access to BGI, highlighted that in extraordinary situations, urban nature can play an essential role in contributing to human well-being and shaping human-nature relationships and the recovery of the post-pandemic world [11,18-20]. That is, the features of a sustainable and resilient city should not only relate to fulfilling economic and social urban strategies, but also to the design and management of urban BGI in order to address current and future societal challenges. For example, around the world, public urban green and blue spaces tend to share similar spatial and visual characteristics (organization of the spaces) because of global trends in designing public open spaces. This pattern has led to the homogeneity of green and blue areas [8] that may or may not afford the same types of benefits in different cities.

The declaration of a global pandemic by the World Health Organization in 2020 led to many governments implementing measures to slow or prevent the spread of COVID-19. The measures included stepwise restrictions in individual mobility and public life in many cities throughout the world. At the same time, in many cities over the world municipalities implemented restrictions of different degrees, including access to and use of urban BGI to help encourage physical distancing $[18,21]$. The value of urban nature in cities during the lockdowns of 2020 revealed that living in a particular neighborhood (place of living), income, and how the government has responded to the pandemic can result in critical differences in the availability and accessibility of BGI $[2,20,22,23]$. Studies $[3,18,20,21,24-26]$ have confirmed that public green and blue spaces play a key role in "building back better". However, the issues of how these differential impacts could influence future urban development that will make the cities sustainable and resilient towards addressing challenges, such as those associated with the COVID-19 pandemic and climate change, need to be better understood. In this sense, the comparison of experiences from cities in different countries could be very valuable.

The research aim was to evaluate perceptions, values, and use of urban green and blue spaces before and after the COVID-19 pandemic restrictions in two cities contrasting in climate, culture, and land-use structure: Moscow (Russia) and Perth (Australia). In particular, the research sought to identify: (a) public perceptions, preferences, and values of urban green and blue spaces during pandemic times; (b) any differences and similarities in responses to COVID-19 restrictions and demands in the organization of urban green and blue spaces between the two cities; (c) how existing urban BGI catered to the needs of citizens during COVID-19 and how this experience can be used during and after extraordinary pandemic situations; (d) which landscape design of urban BGI is needed according to the preferences and values of the respondents to address the current challenges and support people to deal with the COVID-19 restrictions.

A comparison between Moscow and Perth was the main research focus used in this study. As the pandemic was a global issue, we can learn from different experiences how to better use the urban BGI in a time of isolation and lockdown in contrasting cities. Moscow is dominated by publicly accessible green and blue spaces whereas, in Perth, half of the urban vegetation resides on private land (https://tgawa.com.au/green-space-home/ (accessed on 6 March 2021)). Implementation of similar questionnaires for this comparison between the cities explores whether access to public spaces within BGI should be a fundamental strategy of contrasting cities when coping with similar crises. We hypothesized that despite 
the differences in climate, socioeconomics, history, and land-use (private-public access), the response to changes in the accessibility of urban green and blue spaces, their use and qualities would be similar. Research on COVID-19 and BGI published in 2020 is dominated by European Union countries, followed by the US and China. Both countries, Australia and Russia, remain underrepresented (no publication identified during the literature review). In this sense, Moscow and Perth present a useful comparative study, which can provide a different perspective.

\section{Materials and Methods}

The study involved a four-step process starting with preliminary research and identification of the research gap, research design and methodology for data collection, and finally data interpretation and alignment with previous studies.

\subsection{Study Sites}

Moscow and Perth are cities of different sizes, histories, and climates, situated in different hemispheres (Figure 1). The population of Perth is 6 times less than Moscow, and the population density is 15 times less. Compared to Moscow, founded in 1147, Perth is a relatively young city, established by British colonists in 1829, although the Noongar people have occupied the region for more than 40,000 years. While the two cities have different approaches to the organization of urban BGI, some similarities are evident in terms of the philosophy of creating publicly accessible urban spaces. The planning structure, design, and management approach to cities and green and blue spaces in Moscow are very different from the Anglo-American model that characterizes Perth. Despite this, the multifunctional concept of public spaces (e.g., parks for recreation) became an integral feature of urban BGI both in Perth and Moscow. However, in contrast to Moscow, Perth is equipped with a variety of private green spaces which are less common in Moscow where such areas can be mostly seen in the outskirts of suburbia (productive allotment gardens of dachas (or summer cottages), or pure pleasure gardens next to private houses). Moscow, like other Russian cities, has a unique pattern of designing post-Soviet models of publicly accessible urban green and blue spaces and similar social behavior standards such as the use of certain elements of public parks (e.g., lawns, forests, flowerbeds). In Perth, there are large and small public neighborhood parks, sport turf fields, and preserved native bushland. The main types of green and blue spaces in Moscow and Perth are illustrated and briefly described in Table 1.

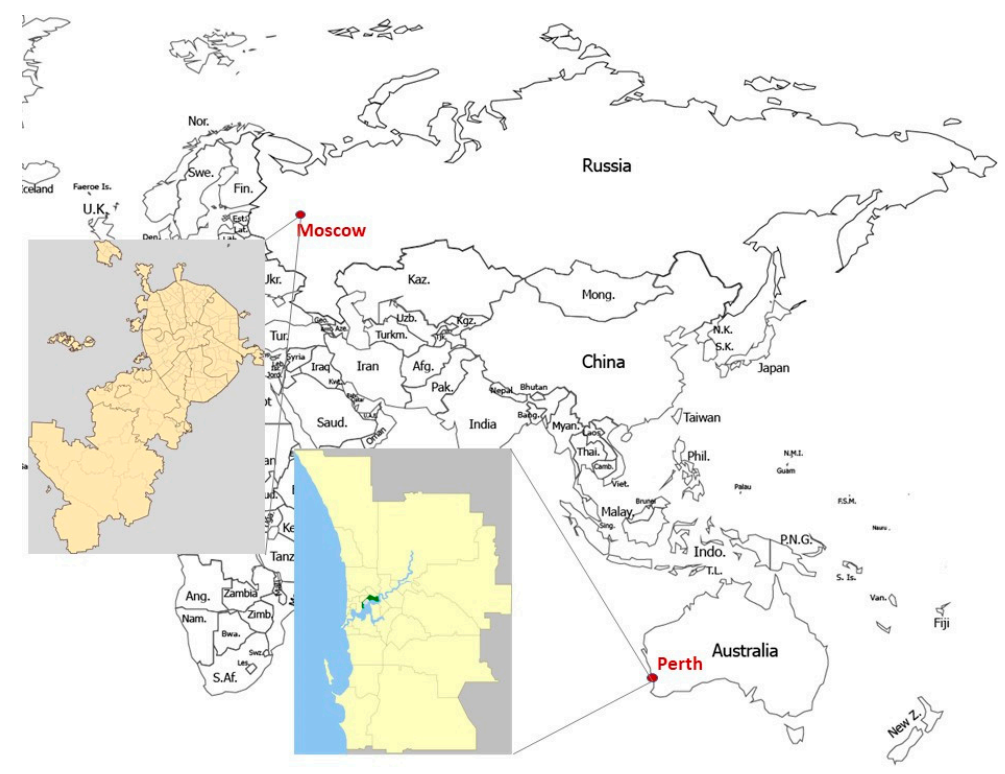

Figure 1. Study area and case study cities. 
Table 1. Main types of green and blue spaces in Moscow and Perth (Photos: M. Ignatieva-Perth, D. Dushkova-Moscow).

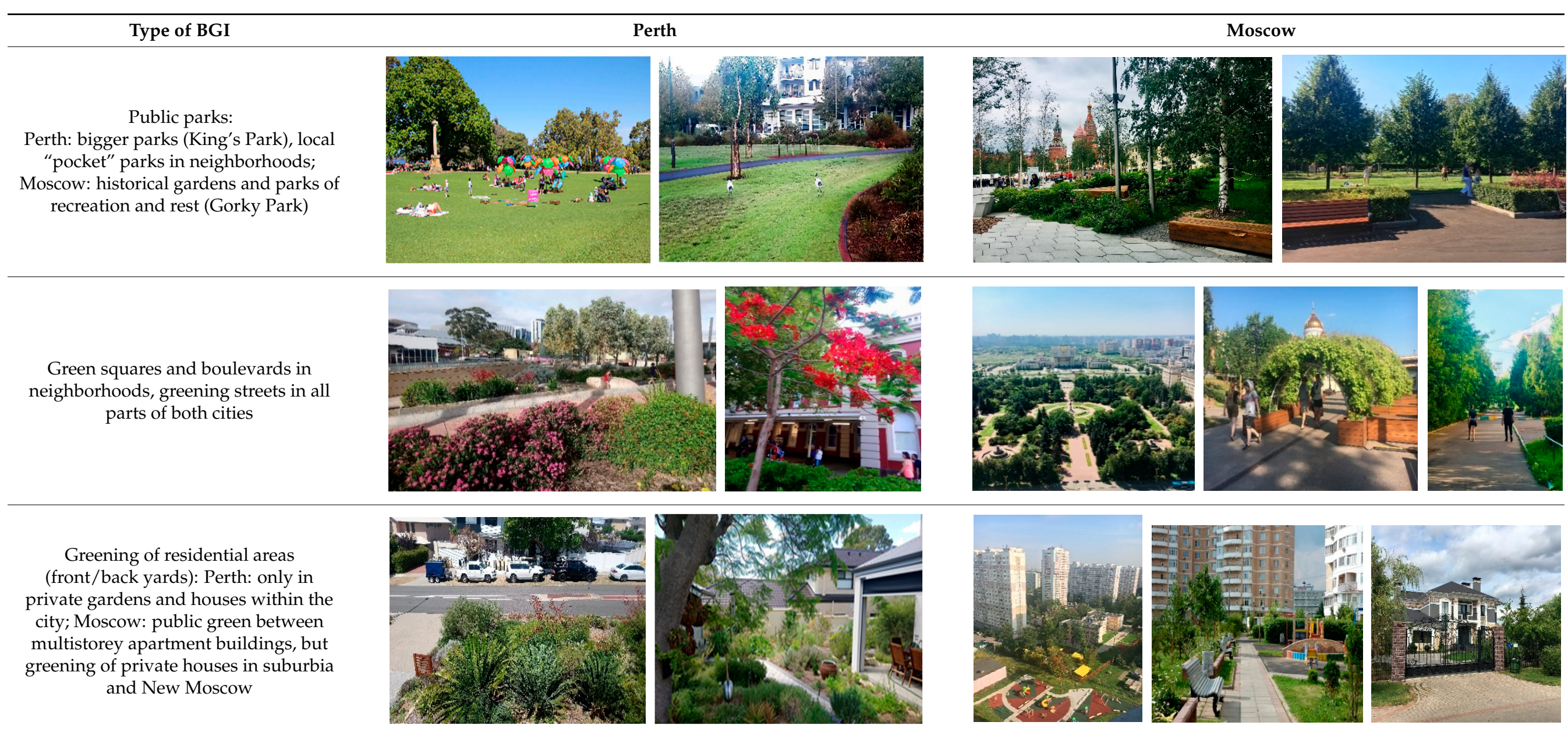


Table 1. Cont

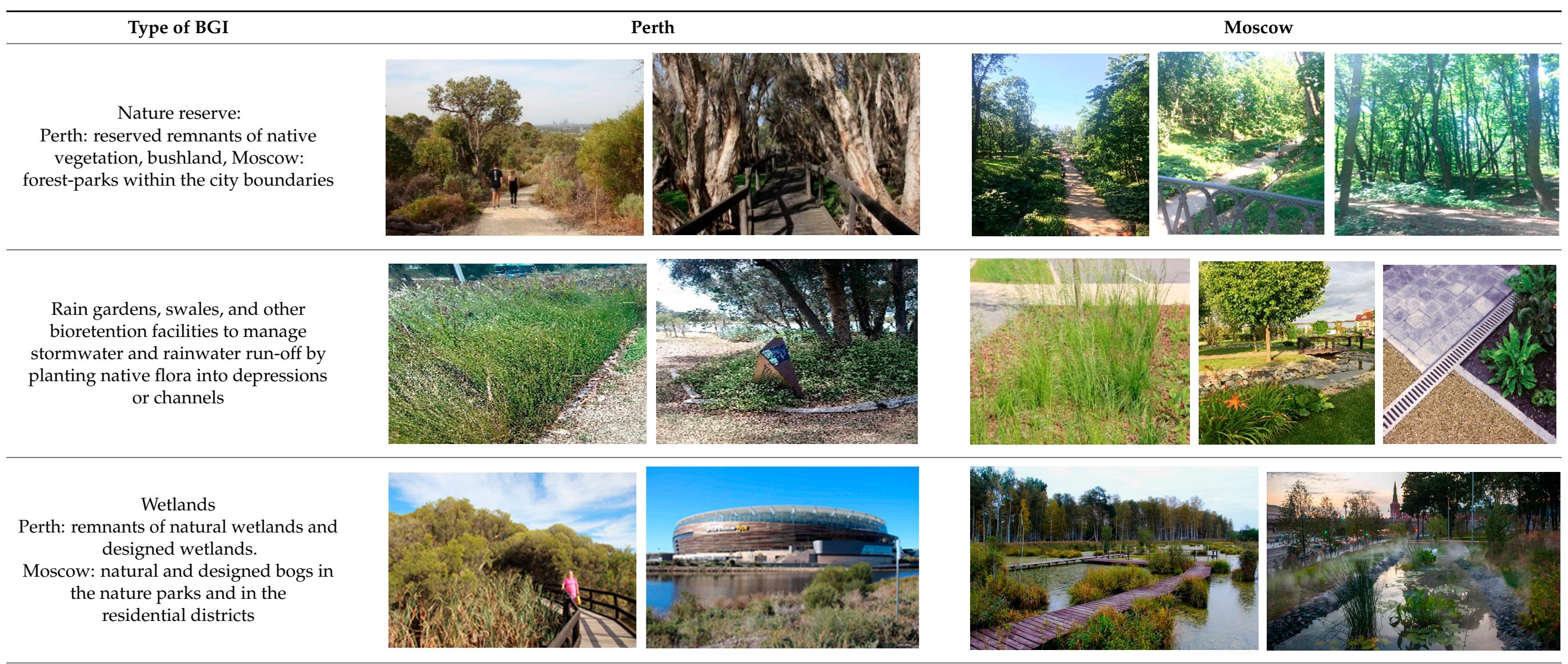


Table 1. Cont.

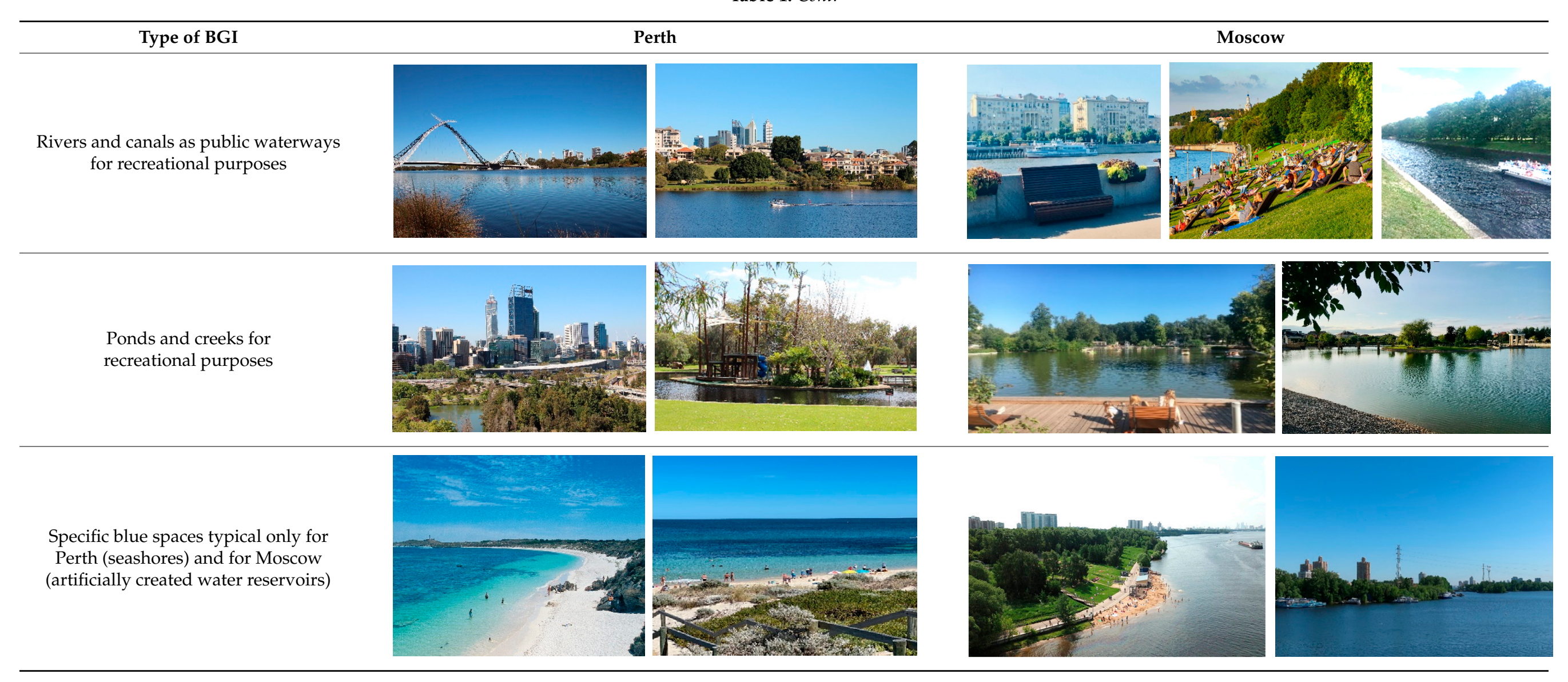




\subsubsection{Perth}

Perth is the state capital of Western Australia and the fourth largest Australian city with a population of about 2.06 million (2018). It is situated on both sides of the Swan River on a coastal plain beside the Indian Ocean. The Perth metropolitan area covers $6418 \mathrm{~km}^{2}$. The climate is Mediterranean with hot dry summers $\left(24.6{ }^{\circ} \mathrm{C}\right.$ mean max temperature) and warm wet winters $\left(12.7^{\circ} \mathrm{C}\right.$ mean minimum), annual rainfall of $850 \mathrm{~mm}$, and with a very high level of daily sunshine, making Perth Australia's sunniest capital city [27]. Perth's warm and sunny climate, accessibility to green and blue spaces, and associated recreation opportunities encourage an outdoor lifestyle for the majority of residents [28].

The planning structure of Perth is based on a classic colonial grid. From the very beginning, Perth was dominated by single-story, owner-occupied homes. A downtown area with high-rise buildings is surrounded by extended low-density suburbs. Green and blue spaces within the city are represented by publicly accessible national parks and nature reserves (based on remnants of native vegetation) and designed urban parks of different sizes, including neighborhood local (pocket) parks planted with mainly exotic and some native plants which utilize global landscape architectural styles. Private gardens are a significant part of Perth's urban green area usually consisting of a front yard (which faces a street) and a more secluded backyard used for recreation (sometimes with productive garden plots, fruit trees, swimming pools, and barbeque areas). Urban public parks and private gardens are irrigated during summer and autumn. Perth is located in the Southwest Australia Ecoregion, one of only 34 internationally recognized Biodiversity Hotspots. These high biodiversity native ecosystems are under significant threat of decline due to habitat destruction and other threats associated with human presence and development [29]. This tension between natural urban green spaces (remnants of native vegetation, bushland) and newly designed green spaces such as parkland is a typical Australian issue. Perth's residents have access to the Swan River and extended seashore. Water-based activities are very popular (surfing, windsurfing, swimming).

\subsubsection{Moscow}

Moscow is the capital of Russia, the biggest city in the country with a population of 12.67 million (2018) (including the New Moscow district) which covers $2500 \mathrm{~km}^{2}$. The city is situated on the banks of the Moskva River, which flows through the East European Plain in central Russia. The climate is humid continental with long, cold (although average by Russian standards) winters usually lasting from mid-November to the end of March, and warm summers. Winter temperatures range from $-25^{\circ} \mathrm{C}$ in the city and $-30^{\circ} \mathrm{C}$ in suburbs to above $5^{\circ} \mathrm{C}$ while summer temperatures range from 10 to $35^{\circ} \mathrm{C}\left(17.2-19.0^{\circ} \mathrm{C}\right.$ mean). Annual precipitation is $707 \mathrm{~mm}$; on average Moscow has $1731 \mathrm{~h}$ of sunshine per year, varying from a low of $8 \%$ in December to $52 \%$ from May to August. Such cold climatic conditions (snow is present for about five months a year, from mid-October to the beginning of April) and the recent change in Moscow's regional climate due to global warming (extreme heat is more frequent in the city and has reached $37.8-38.2^{\circ} \mathrm{C}$ ). These extremes act as limiting factors for outdoor recreation. Moscow has a well-developed urban BGI consisting of remnants of native vegetation (recreational forest and forest-parks), public districts and local community parks, and green spaces within local neighborhoods within the residential block of houses [6]. Moscow has a significant number of historical parks and gardens of the 18th and 19th centuries under governmental protection. The city experienced devastating bombing and the related destruction of green areas during the Great Patriotic War (1941-1945). After the war, the greening of newly created "microrayons" (residential clusters of 30-50 ha for 12,000-15,000 people, consisting of multi-story government housing for families) resulted in the establishment of extensive public residential green and blue spaces. Moscow has an extensive forest-park zone for short-term recreational use based on native forests but containing planned and designed elements [6]. Within the Moscow city boundaries, there are 150 small rivers and streams, as well as about 240 open reservoirs (ponds and lakes). Most of the small rivers in the city are regulated or canalized (Table 1). 


\subsection{Data Collection}

The information on the chronicle of COVID-19 in both cities and the overall effects of COVID-19 on the aspects related to urban green and blue spaces were collected from government documents and literature resources.

Survey data were collected using an online, fixed item, anonymous questionnaire distributed simultaneously in Perth and Moscow. The sample was restricted to residents living in metropolitan areas. Twenty-five questions, written in the respective local language (English or Russian), focused on the self-reported effects of measures taken to limit the spread of COVID-19 on a sample of city dwellers, and their perceived value and use of urban green and blue spaces.

\subsection{Questionnaire Design}

The questionnaire consisted of 25 questions developed by the researchers and included six general components:

1. information on the area of residence (for geographical identification to confirm the respondent was in the metropolitan sample area, the extent/provision of urban BGI in the area, and how long each area was under lockdown);

2. subjective values assigned to urban green and blue spaces;

3. perceived personal impacts of COVID-19 related restrictions;

4. self-reported impacts of COVID-19 restrictions on access to urban green and blue spaces;

5. subjective assessment of urban green and blue spaces adequacy and quality in the respondents' local neighborhood;

6. general demographic information.

The subjective values component of the questionnaire focused on the perceived importance of access to urban nature in terms of personal well-being and perceived personal benefits. Two six-point Likert scale questions rated the importance of accessing nature for mental and physical well-being respectively (six-point scale from very unimportant to very important and additional option for answering "I don't know"). A subsequent question asked respondents to select one or more perceived benefits of urban BGI (including "none" and "other" options) from a list of options provided. Benefit options were derived from the scholarly literature $[30,31]$.

The personal impacts of COVID-19 restrictions included two six-point Likert scale questions (very negative to very positive, an additional option, "I don't know") rating the personal impact of lockdowns, social distancing, and working from home on daily life and well-being. One multiple-choice question asked respondents to select one or more actions taken to cope with quarantine challenges (including "none" and "other"). One question asked respondents to indicate where they preferred to access urban BGI during restrictions. Three questions asked respondents to indicate from a list of options how frequently they accessed urban BGI before, during, and after COVID-19 restrictions respectively.

The subjective assessment of urban green and blue space abundance and quality in the respondents' local neighborhood used two questions each with three options (agree, disagree, and don't know) in the context of COVID-19 restrictions. If respondents indicated that urban green and blue space in their neighborhood was inadequate, then two subsequent questions requested the respondent's preferred additional urban green space (UGS) types and what additional design or infrastructure elements they would add to the green space they most commonly used by selecting options from a list (including "nothing" and "other") [32,33].

Finally, the questionnaire included general demographic questions on respondent gender, age, level of education, current main occupation, resident postcode, dwelling type, and the number of people living in the household.

\subsection{Survey Distribution}

The Moscow online survey was distributed using the online survey tool Survio (survio.com) and advertised on the Russian social network Vkontakte (vk.com). The Perth 
online survey was distributed using the Qualtrics online survey tool (Qualitrics.com) and email. An invitation to complete the Perth questionnaire was sent by email to each of the researchers' professional and social networks resident in the Perth metropolitan area. The email invitation also encouraged participants to forward the questionnaire to others in their own networks. This snowball sampling approach extended the sample to a broader pool of participants residing in Perth. Two weeks after the initial email invitation, a second invitation was sent to the original list of potential participants thanking them for their participation and encouraging them to complete the survey and forward it to others in their networks. Both the Moscow and Perth online questionnaires were active from May to July 2020.

The survey period in Moscow was in late spring and summer with the temperature range being $20-35^{\circ} \mathrm{C}$ (which is the most important outdoor activity season). The survey period for Perth was during late winter-early spring with temperatures between $14-21^{\circ} \mathrm{C}$ which is also a comfortable season for outdoor activity.

The respondents' locations were georeferenced based on the postcodes (centroids of the polygons corresponding to a particular postcode were created) (Figure 2).

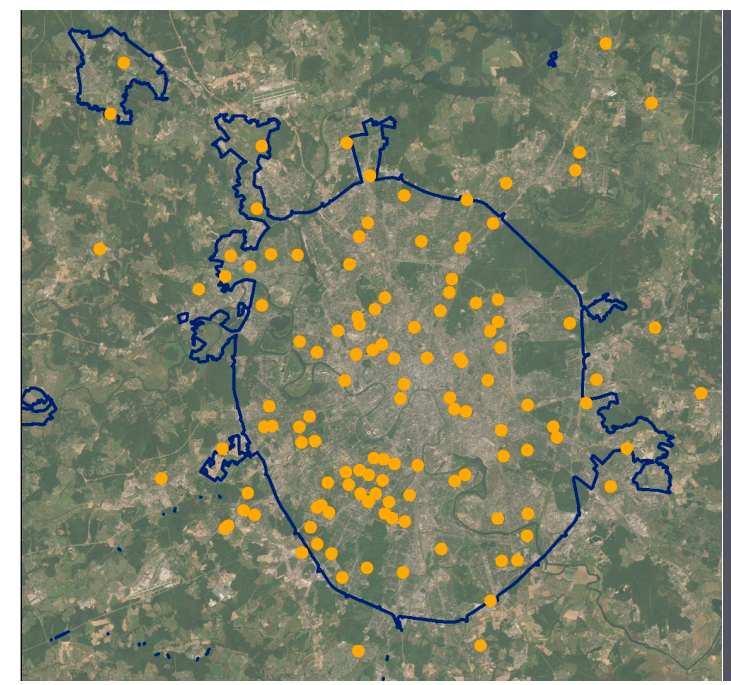

(a)

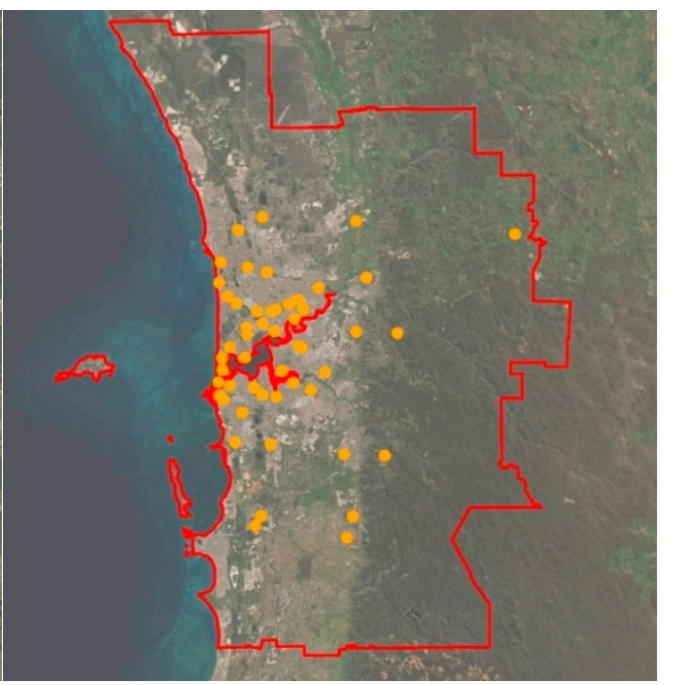

(b)

Figure 2. Spatial distribution of respondents within the city in Moscow (a) and Perth (b). Note: since the respondents are mostly distributed within the boundaries of Old Moscow, the district of New Moscow is not included in the figure.

\subsection{Data Analysis}

The Russian language questionnaire responses were translated into English and combined with the Perth data set. A multiple-choice design reduced potential translation errors in terms of intended meaning as the structure of the English and Russian language questionnaires were the same. Analysis of the data was conducted using the SPSS software (IBM SPSS v24). This analysis included descriptive statistics as well as Chi-square tests of association for categorical data and nonparametric tests (such as Mann-Whitney $\mathrm{U}$ and Kruskal Wallis tests) for ordinal data.

Of 119,385 people invited to participate in the survey by Vkontakte advertisement, 988 people visited the entry page of the questionnaire on Survio, and 280 of them completed the survey, 59 respondents did not live in the Moscow agglomeration and thus were excluded. The final sample providing data for the present study included 216 respondents.

The initial combined email invite list for Perth included a total of 84 people invited to participate. Using a snowball principle, a total of 110 Perth residents completed the questionnaire. 


\section{Results}

The case studies focused on differences and similarities in public perception of urban green and blue spaces during pandemics in two different cities. The main emphasis was on the comparison of residents of Moscow and Perth as a whole group, rather than on different socio-demographic groups. The data sample was rather small-216 in Moscow and 110 in Perth. This refers to the limitation of the online survey method. This was a pilot study that aimed to find out the specific patterns of urban nature perception by citizens and its values during and after pandemics.

\subsection{Chronicle of COVID-19 Pandemic and Analysis of Its Impact}

The first confirmed cases of COVID-19 in Perth (21 February 2020) and in Moscow (2 March 2020) were dated approximately the same time. However, the main measures to prevent viral spread varied during the four following months. The timelines of these measures and their cancellation are presented in Figure 3.

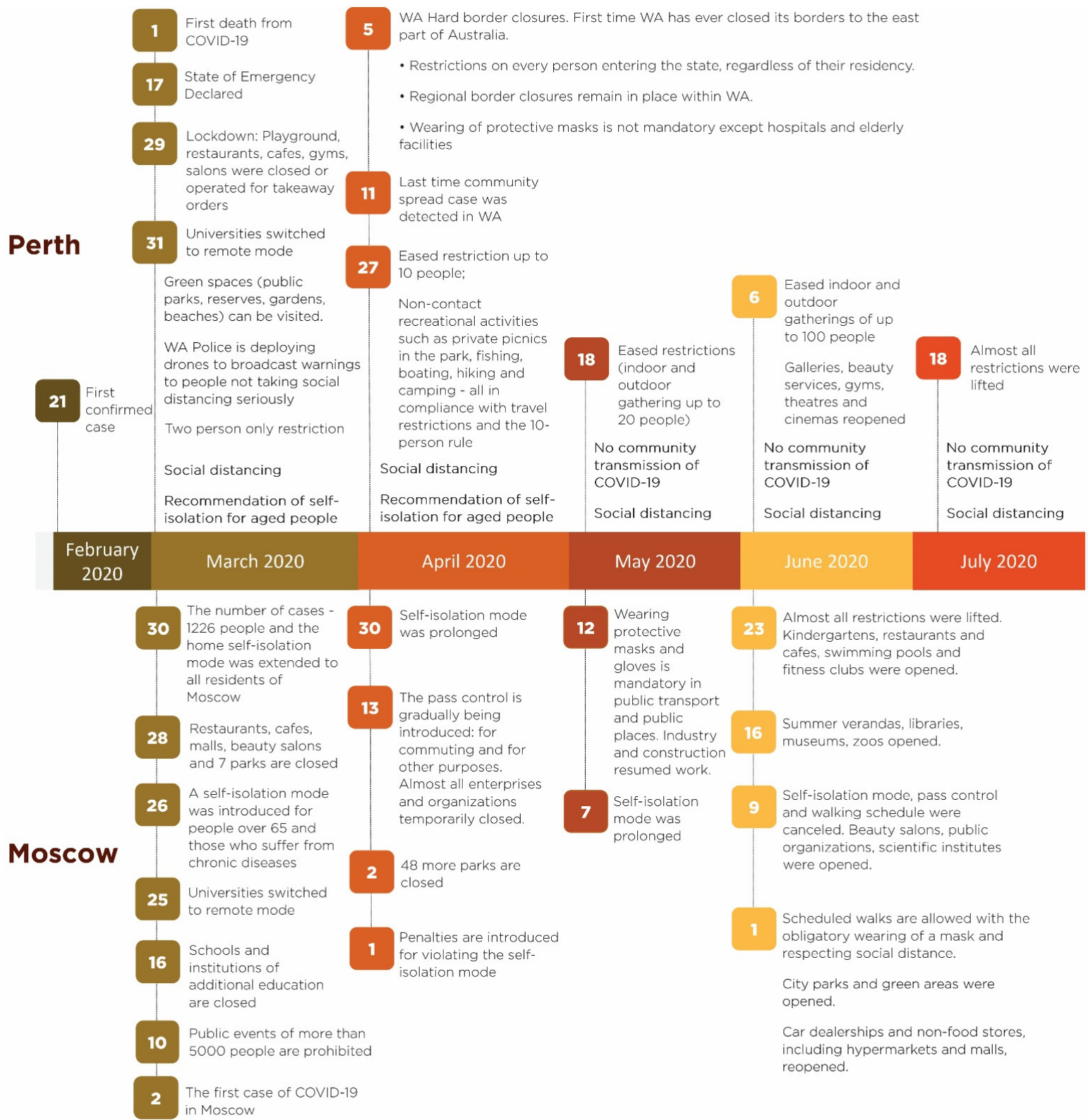

Figure 3. The timeline of the main measures to prevent the COVID-19 pandemic and their cancellation in Moscow and Perth. 
There were similar measures in the two cities especially in the first month of the pandemic where playgrounds, restaurants and cafes, sports infrastructure were closed, universities were switched to remote mode, social distancing and self-isolation for aged people were recommended. However, in the following months, the measures in Moscow became more stringent (Figure 3). Measures included not only the closure of 55 public parks banning visits to green and blue areas (Figure 4) but a full lockdown for 1.5 months. The self-isolation regime (home quarantine) in Moscow lasted from 30 March to 9 June 2020. There were few exceptions that allowed going outside, for example, a necessity to be at the workplace, shopping at the nearest food store or pharmacy, walking pets within a distance of $100 \mathrm{~m}$ from the place of residence, taking out the garbage, seeking emergency medical help, or a direct threat to life and health. From 12 May 2020, wearing protective masks and gloves was mandatory in public transport and other public places.

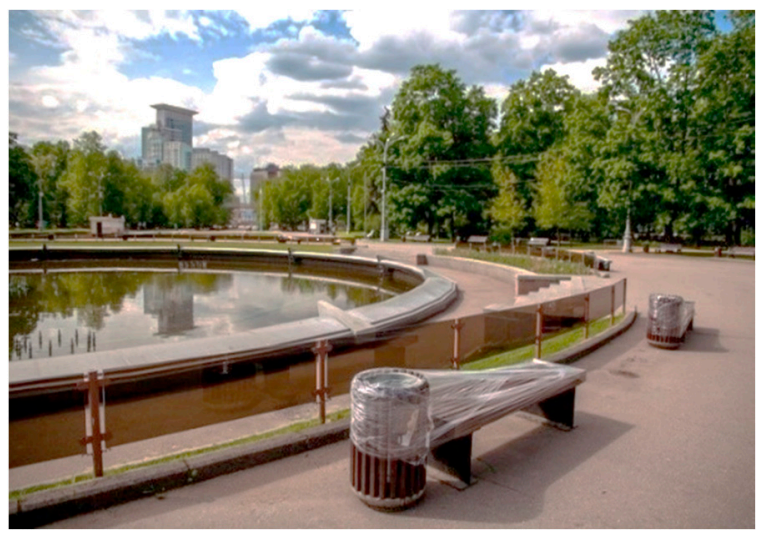

(a)

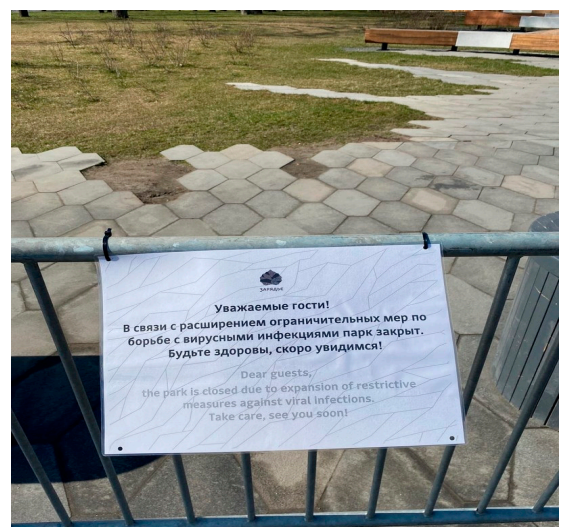

(b)

Figure 4. Due to sanitary restrictions in the spring and early summer, most public parks in Moscow were closed to visitors during the first lockdown. Sokolniki public park of recreation in the Eastern part of Moscow (a) and Zaryadye park in the city center (b) (Photos: Kosenkov E.).

On the contrary, during 2020 the wearing of masks was not mandatory in Perth (Figure 3). However, a state of emergency was declared, and the borders of the state were closed to international and interstate travelers for the first time in its history. Despite the restrictions, urban green and blue spaces (public parks, reserves, gardens, beaches) were open during the whole 2020 period of the pandemic, although the use of exercise and children's play equipment located in urban green and blue spaces was not allowed. Their use in Perth was restricted to non-contact recreational activities such as picnics in the park.

In June-July 2020, most of the restrictions were lifted both in Perth and in Moscow.

Analysis of some key parameters that appeared in the literature indicated that lockdowns during the COVID-19 pandemic had some direct, short-term, positive impacts on the environment of both cities, especially in terms of emissions and air quality, mostly due to reduced traffic. Wildlife also benefited from less traffic and the absence of people, although these were likely to be temporary (Table 2, Figures 4 and 5). There was also a documented positive shift in community attitudes towards green spaces (visitation rates for Perth and Moscow increased). However, there were also several negative consequences of lockdowns (e.g., influence on physical and mental health, and domestic violence). 
Table 2. Impacts of COVID-19 restrictions on the populations of Perth and Moscow.

\begin{tabular}{|c|c|c|}
\hline Parameter & Moscow & Perth \\
\hline Reduced physical activity & $\begin{array}{l}\text { Due to several restrictions (The Mayor of } \\
\text { Moscow allowed outdoor sports activities } \\
\text { only until } 9 \text { p.m. and walking within } 2 \\
\text { km distance from home only three times } \\
\text { a week without sitting on the benches), } \\
\text { physical activities were reduced [34] }\end{array}$ & $\begin{array}{c}\text { Some Perth people may have shifted to } \\
\text { physical activity indoors given a reported } \\
\text { spike in purchasing gym equipment and } \\
\text { online fitness training [35] }\end{array}$ \\
\hline
\end{tabular}

More than half of people who have had a severe form of coronavirus subsequently experience depression, insomnia, panic attacks, and other generalized mental disorders defined as post-COVID syndrome. COVID-19 strongly affects people's daily emotional lives, increasing Negative influence on mental health stress levels due to the lockdown period lengthens the fear of getting sick, or financial difficulties, especially by families with children. Online or phone calls to psychotherapists and psychologists were perceived as not real supportive measures due to the absence of physical contacts [36]

The number of victims of violence and cases of domestic violence has increased by 2.5 times since April 10 and during the whole pandemic [38]

Domestic violence

Passenger use of public transport in

Reduced traffic

May-June 2020 was reduced to $54.5 \%$ of that in January-March 2020 [39]

For carbon monoxide, experts recorded a

Reduced air pollution decrease of $11 \%$, and for sulfur dioxide by $30 \%$ [41]
It has been reported that calls to mental health helplines, such as the Beyond Blue COVID-19 line, increased. Social isolation and anxiety associated with the public health response had a major impact on vulnerable cohorts (particularly seniors and people with disabilities, and their careers) and compounded mental health issues [37]

Increases in family violence incidents of around 5\% between March and May 2020 compared to the same time in 2019 [37]

A 79\% drop in public transport use in

Perth, road traffic had dropped $47 \%$, walking journeys were down $37 \%$ (end of April) [40]

Almost no change in nitrogen dioxide emission [42]

Increase in the appreciation and demand for open public spaces, as outlined by Greener Spaces Better Places. A total of $87 \%$ of Australian urban councils had noted a positive shift in community attitudes towards green space [44]

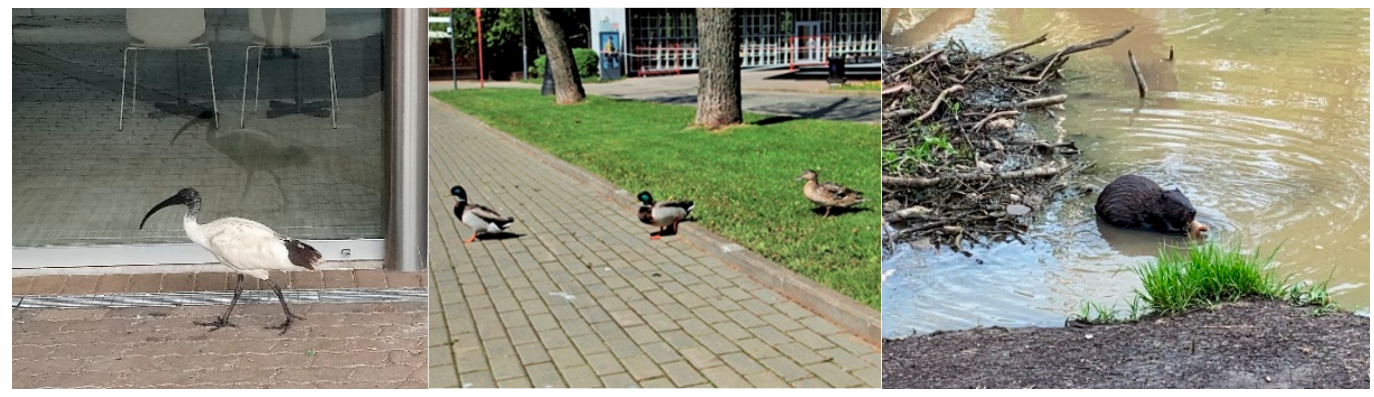

(a)

(b)

(c)

Figure 5. Presence of wildlife during the pandemic: increase in the prevalence of some species such Ibis next to the WA National Gallery in Perth (a), duck in Izmaylovo public park (b); beaver is back in the public park of Novoperedelkino in New Moscow (c) (Photos: Ignatieva M., Kosenkov E., and Konstantinova A.). 


\subsection{Social Survey Results}

\subsubsection{Description of Samples}

The respondent gender ratio was similar for both cities. The majority of the respondents were female with $72.7 \%$ in Moscow and $61 \%$ in Perth. The age range distribution in Perth was near to normal with two peaks of 40-45 and 65 years old. In Moscow, the most frequent age range of respondents was $20-40$ years old. Full-time employment was the dominant category: $48.5 \%$ in Perth and $40.5 \%$ in Moscow. One of the main differences between the samples was the type of housing. Most of the Perth respondents (78.2\%) reported living in detached houses while respondents in Moscow more frequently lived in a flat, apartment, or townhouse (81.4\%). The mean number of people living in each respondent household (including children) was 2.74 people in Perth and 2.28 people in Moscow.

\subsubsection{The Main Challenges of COVID-19 Restrictions}

Respondents in both cities rated the impact of working from home much more positively for daily life routine (mean $=3.15$ for Perth and 3.51 for Moscow) and for personal well-being (mean $=3.14$ for Perth and 3.31 for Moscow) than lockdowns and social distancing (both rated between negative and neutral) (Figure 6). In addition, Moscow respondents rated working from home more positively compared to the Perth respondents rating in terms of both impacts on daily life and personal well-being.

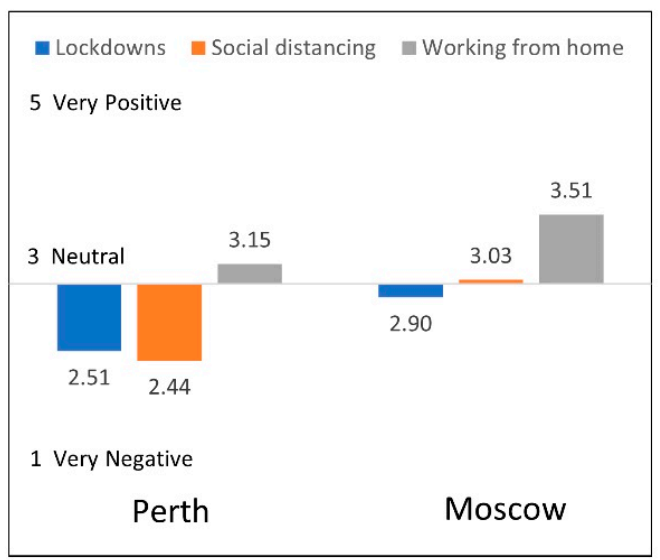

(a)

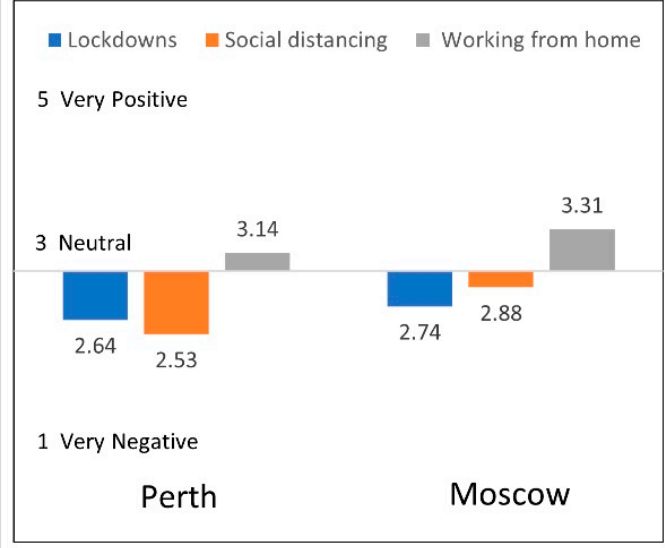

(b)

Figure 6. Mean rating of perceived impact of COVID-19 restrictions on (a) respondents' daily life and routine in Perth ( $\mathrm{n}=$ 99-lockdowns; $\mathrm{n}=101$-social distancing; $\mathrm{n}=95$-working from home) and Moscow $(\mathrm{n}=216)$ and $(\mathbf{b})$ respondents' personal well-being in Perth ( $\mathrm{n}=100$-lockdowns; $\mathrm{n}=101$ - social distancing; $\mathrm{n}=96$-working from home) and Moscow $(\mathrm{n}=216)$.

Social distancing was rated as a significantly less negative impact by respondents in Moscow compared to those in Perth for both daily life $(\mathrm{U}=8108, p=0.000)$ and personal well-being $(\mathrm{U}=8943.5, p=0.004)$. However, Moscow and Perth respondent ratings for the impact of lockdowns (daily life $(p=0.087, \mathbf{U}=9874)$, personal well-being $(p=0.682$, $\mathrm{U}=10,824$ ), and working from home (daily life $\mathrm{U}=9712.5 p=0.103$; personal well-being $(\mathrm{U}=10,511.5 p=0.686))$ were not significantly different.

\subsubsection{Perceived Benefits of COVID Restrictions}

All respondents indicated some positive benefits of COVID restrictions including reduced traffic on roads, reduced urban noise, cleaner air, more wildlife, and the opportunity to spend more time in green spaces. This correlates well with the official data on the COVID-19 influence presented in Table 2. The most frequent responses were associated with changes in human activity, including: less traffic on the roads $(75.5 \%$ in Perth and $46.8 \%$ in Moscow), reduced urban noise (42.9\% in Perth and 31.5\% in Moscow), the streets 
and neighborhoods being less crowded (35.7\% in Perth and $49.1 \%$ in Moscow). While about $15 \%$ of respondents in Moscow indicated no perceived benefits, $25 \%$ rethought their lifestyle intending to make it less stressful and rushed (Figure 7).

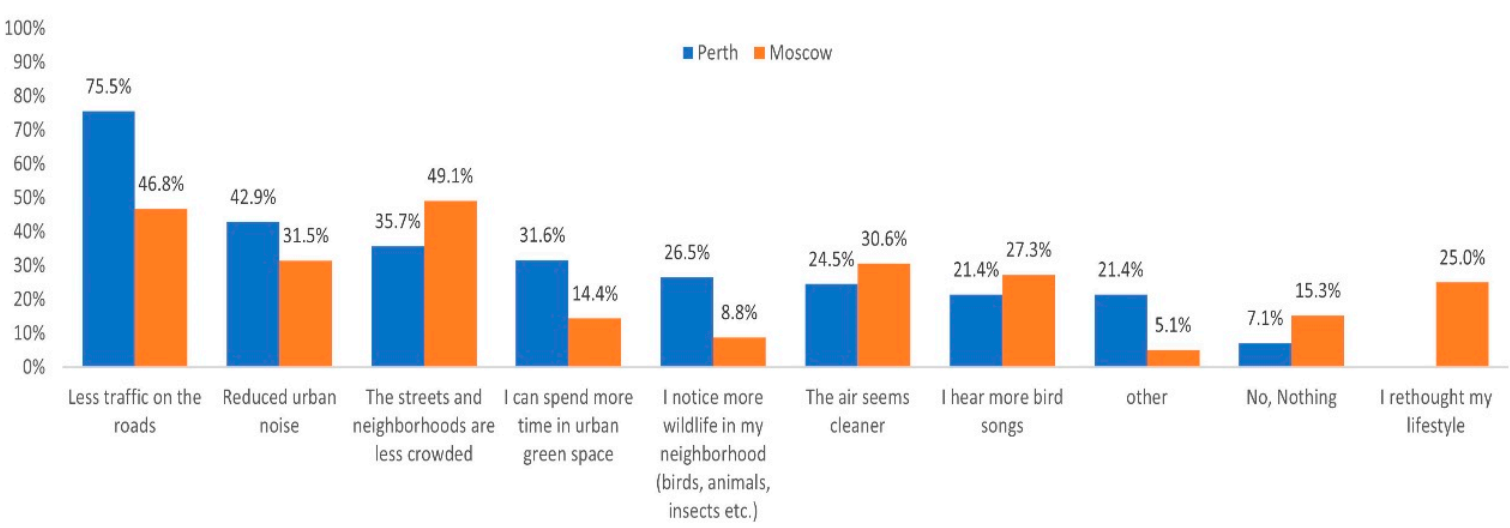

Figure 7. Perceived personal benefits of COVID-19 restrictions in Perth $(n=98)$ and Moscow $(n=216)$.

\subsubsection{Activities to Cope with COVID Restrictions}

In both cities, the most frequently selected activity to cope with COVID-19 restrictions was taking a walk outside (72.7\% Perth and 50.5\% Moscow) (Figure 8). The main difference between the two cities was outdoor physical exercise. For Perth respondents, this was the second most frequently selected activity $(42.5 \%)$ while this was the least frequent activity for respondents in Moscow (apart from "do nothing"). Doing indoor exercise was the second most frequent activity for Moscow respondents (52.8\%). Accordingly, physical exercise (either outdoors or indoors) was identified as one of the most important coping strategies in both cities.
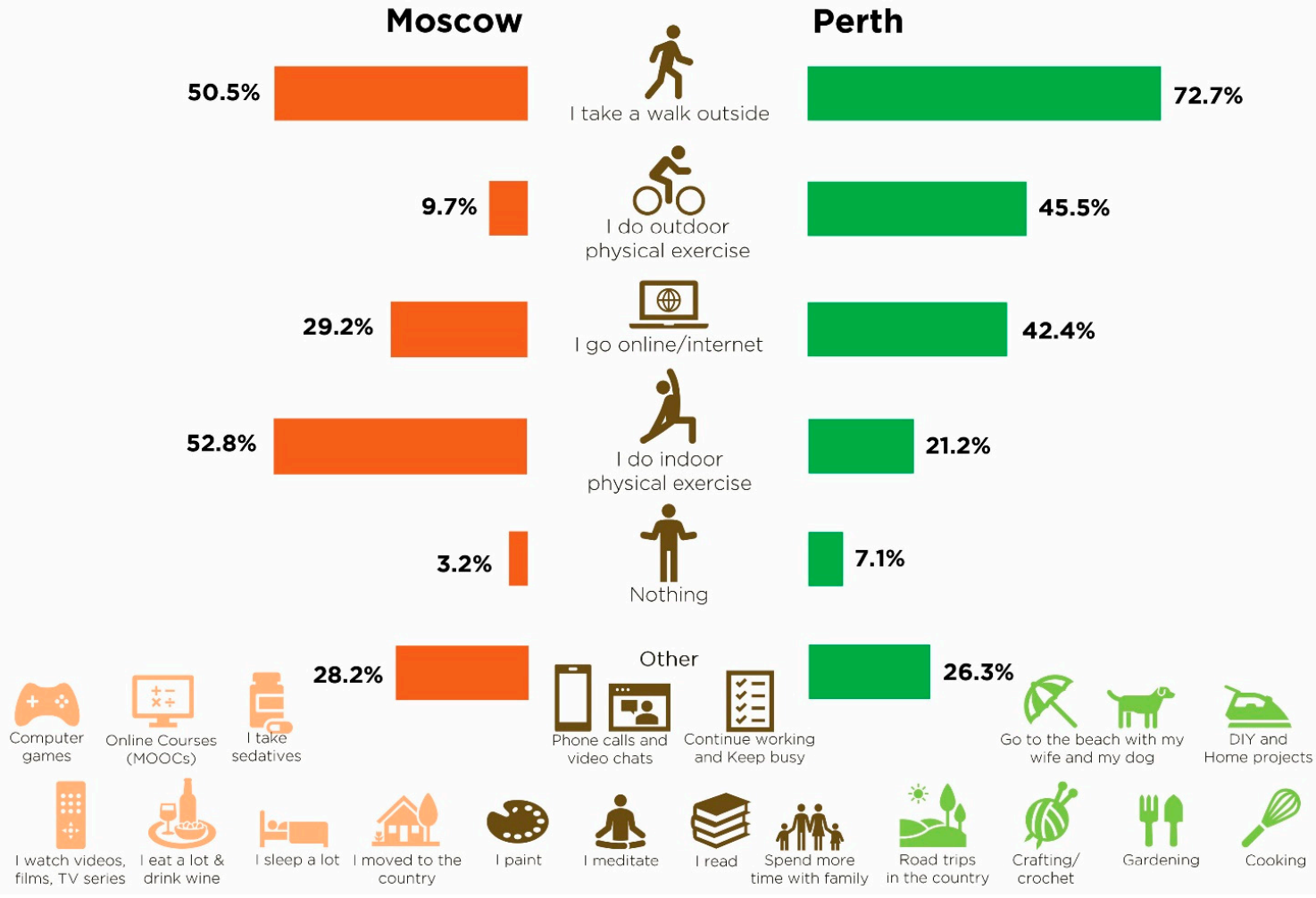

Figure 8. Activities to cope with COVID restrictions in Perth $(n=99)$ and Moscow $(n=216)$. 


\subsubsection{Importance of Contact with Nature for Physical and Mental Well-Being}

All respondents in both cities highly valued urban green and blue spaces for physical and mental well-being. Most respondents in both Moscow and Perth rated contact with nature as important or very important for physical and mental well-being (Figure 9). This importance is statistically significant for both physical $(\mathrm{U}=9368, p=0.009)$, and mental wellbeing $(\mathrm{U}=8488, p=0.000)$. However, a comparison between Perth and Moscow indicates no significant correlation between the city variable and reported physical $(r=0.147)$ and mental well-being $(r=0.263)$ variables. In this case, the importance of nature contact did not depend on the city, although Perth respondents rated contact with nature higher (more than $97 \%$ for mental well-being and $85 \%$ for physical well-being) compared to Moscow respondents (more than $76 \%$ for mental well-being and $70 \%$ for physical well-being).

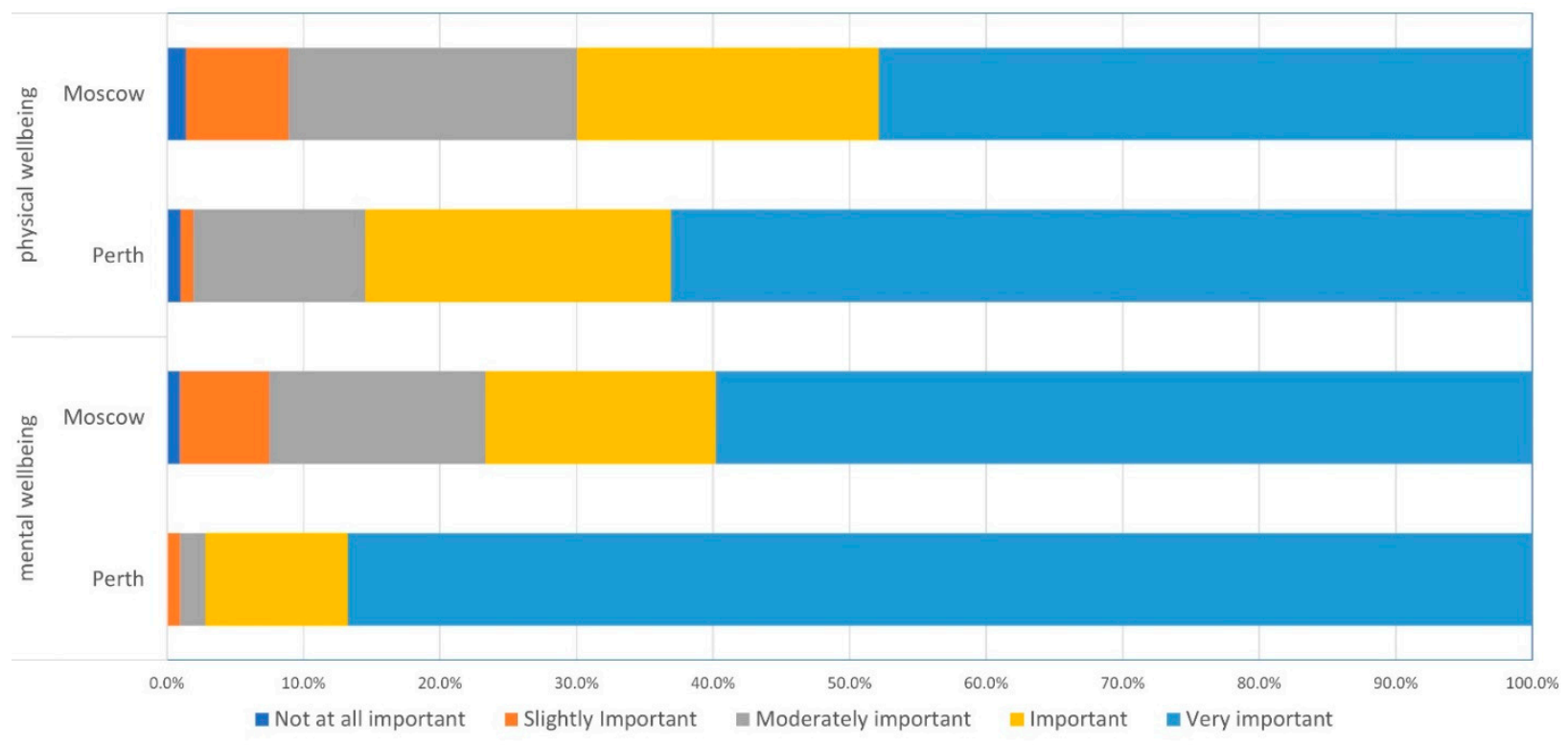

Figure 9. Importance of urban green and blue spaces for physical and mental well-being in Perth $(\mathrm{n}=101)$ and Moscow $(n=216)$.

\subsubsection{Perceived Personal Benefits of UGS}

Among perceived personal benefits, "breathe fresh air" (86.7\% in Perth and $85.1 \%$ in Moscow), "connect with nature" (82.9\% in Perth and 51.6\% in Moscow), "enjoy scenic beauty" (89.5\% in Perth and $71.2 \%$ in Moscow), and "a place to relax and unwind" (81.9\% in Perth and $68.4 \%$ in Moscow) were among the most frequently selected benefits in both cities. In Moscow, urban green and blue spaces were popular for sunbathing. Due to the short summer in the northern hemisphere, sunbathing is a very popular pastime in Moscow (Figure 10).

At the same time, "mental health benefits" (83.8\% in Perth and 71.2\% in Moscow) and "a place for physical exercise" (76.2\% in Perth and 50.7\% in Moscow) were also strongly associated with urban green and blue spaces. 


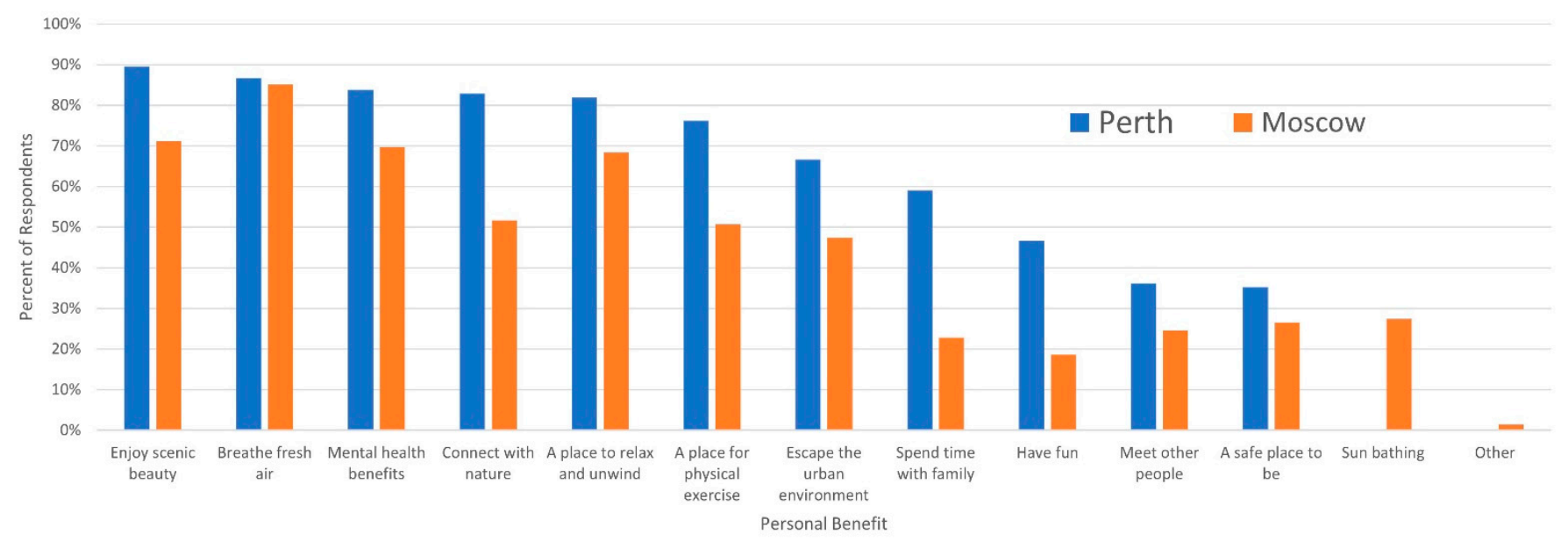

Figure 10. Perceived personal benefits of urban green and blue spaces in Perth $(n=101)$ and Moscow $(n=216)$.

\subsubsection{Changes in Urban Green and Blue Spaces Visitation}

The change in visiting green and blue spaces before and during the pandemic is especially evident in Moscow, where visits were officially restricted. Here $56.9 \%$ of respondents visited green and blue areas less often (Figure 11b). At the same time, $35.6 \%$ of Moscow residents retained the frequency of visits, and $7.4 \%$ increased, despite the limitations on access to urban green and blue spaces. The majority of Perth residents (59.4\%) did not change their frequency of urban green and blue spaces visits, while $26.7 \%$ increased them.

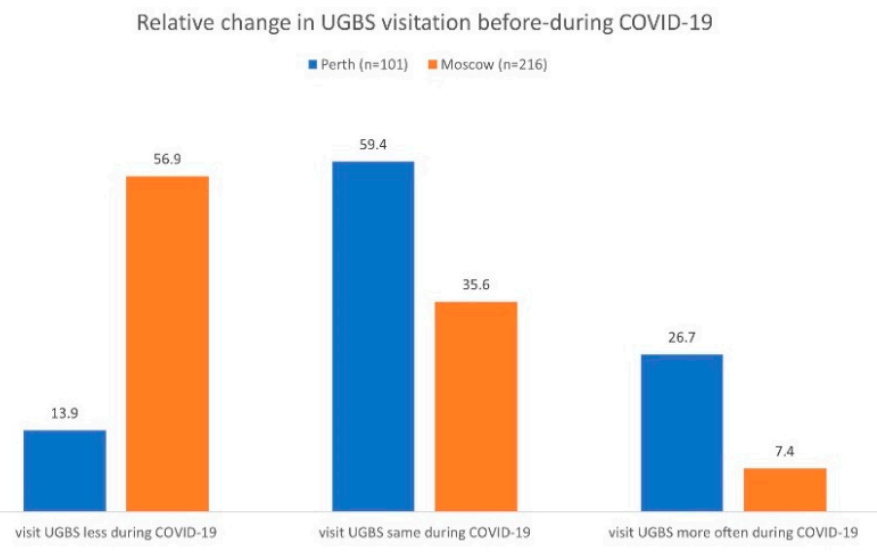

(a)

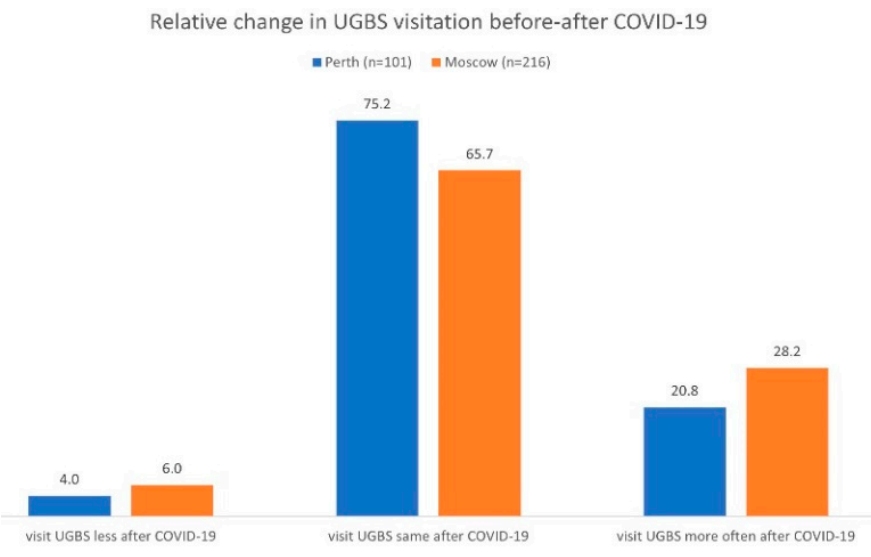

(b)

Figure 11. Reported changes in urban green and blue space (UGBS) visitation: (a) during the COVID-19 restrictions relative to green and blue space visitation before COVID-19 restrictions; (b) after the COVID-19 restrictions relative to green and blue space visitation before COVID-19 restrictions.

The response indicates that after the pandemic, most respondents reported they would not change their green and blue spaces visit frequency and most of them $(75.2 \%$ in Perth and $65.7 \%$ in Moscow) would return to regular pre-pandemic frequency of visits (Figure 11a). However, more than a quarter of Muscovites (28.2\%) and a fifth of Perth residents (20.8\%) reported they would increase their visits to green and blue areas.

\subsubsection{Urban Green and Blue Spaces Access Preferences and Demand}

Having access to a nearby local park was the most frequently selected option for respondents in both cities (Figure 12). Most Perth respondents indicated a stronger preference for private gardens compared to Moscow respondents. This difference was likely due 
to the relative availability of private gardens in each city. Natural areas outside the city were considered quite valuable in both cases as well.

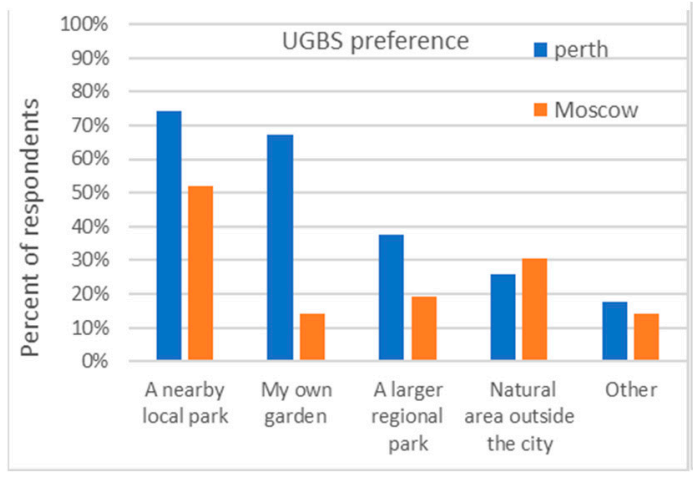

(a)

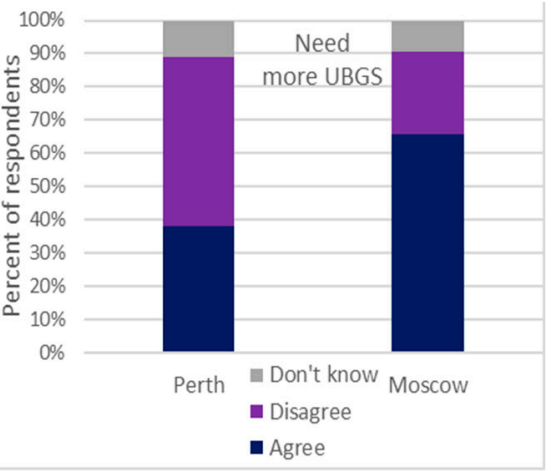

(b)

Figure 12. Urban green and blue space access preference in Perth $(n=101)$ and Moscow $(n=216)(a)$ and demand for green and blue spaces (improvements in urban blue and green infrastructure (BGI) according to respondents) in Perth ( $\mathrm{n}=100)$ and Moscow $(\mathrm{n}=216)(\mathrm{b})$.

For the question regarding the current needs and additional types of urban green and blue spaces, most respondents from both Moscow (55\%) and Perth $(77 \%)$ indicated more street greening was the most desired measure (Figure 13). Other frequently selected types by Perth respondents were natural bushland $(60 \%)$ as well as green front and back yards $(56 \%)$. Moscow respondents wanted more pocket parks and small gardens $(49 \%)$ as well as more residential green space ( $48 \%)$. Both Perth and Moscow respondents wanted more public green spaces near their houses $(45 \%, 45 \%)$ and more public parks.

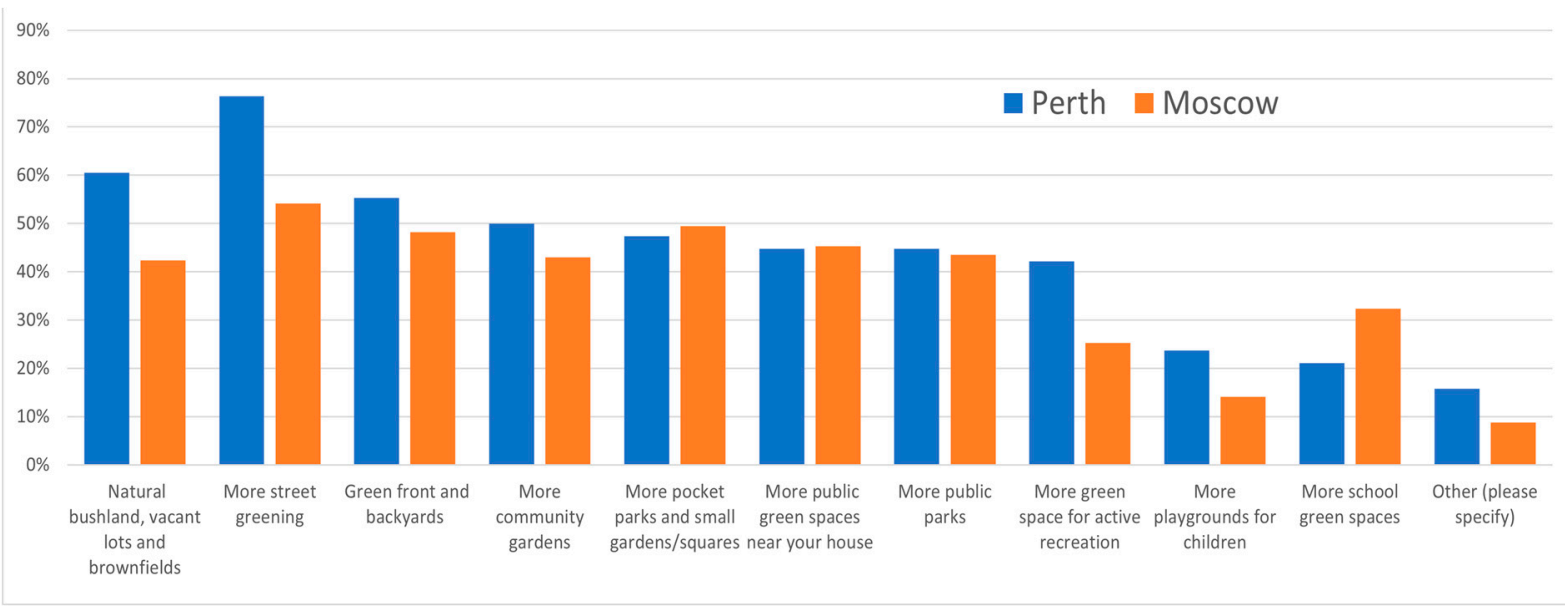

Figure 13. Additional types of green and blue spaces mentioned as current needs in BGI in Perth $(\mathrm{n}=38)$ and Moscow $(n=170)$.

In terms of green and blue spaces features and infrastructure, respondents in both cities indicated a need for more benches (sitting places) in their green spaces (Figure 14). For Moscow, $49 \%$ of responses referred to the need for more shady places while for Perth the most frequently indicated improvement was "places for sheltering from the rain". Respondents in both cities indicated a preference for the installation of more signs with additional information about green and blue spaces. Moscow respondents were in favor of water features (fountains and ponds) and green elements such as green walls and arbors to a greater extent than Perth respondents. Perth respondents more frequently indicated a preference for additional garden beds for vegetables and fruits. 


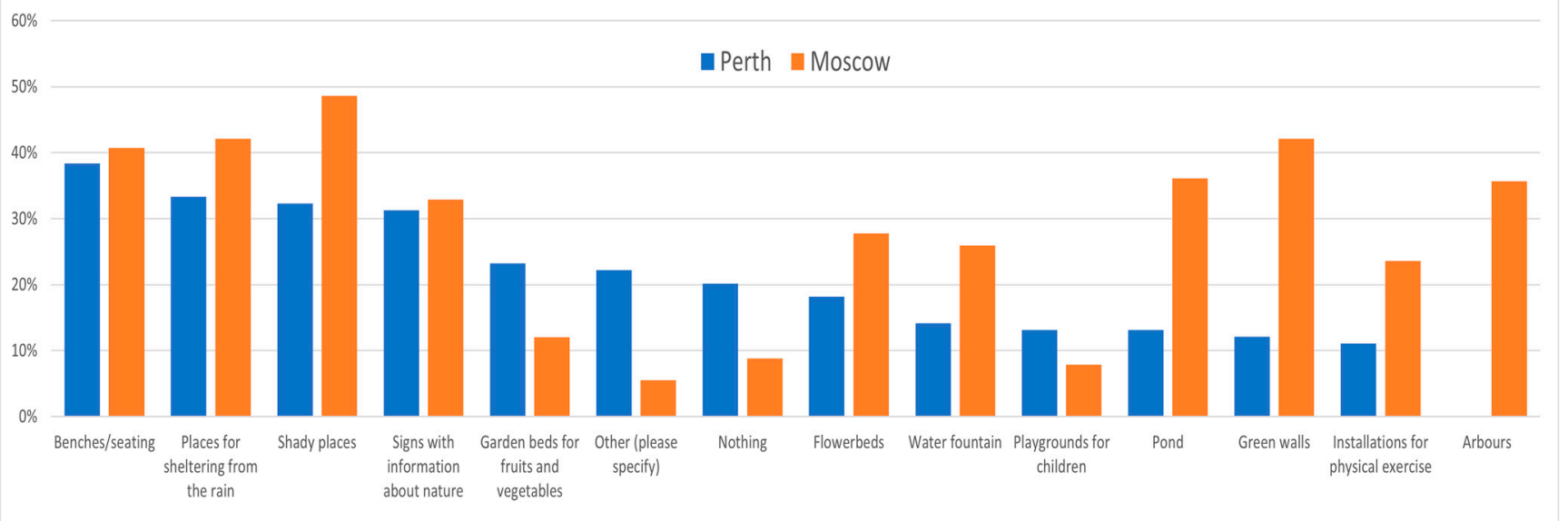

Figure 14. Additional features/infrastructure elements for improvement of BGI in Perth $(n=99)$ and Moscow $(n=216)$.

\section{Discussion}

We compared the self-reported impacts of COVID on people's lifestyles and use of urban BGI in a large and dense city that followed the urban design patterns of the dominancy of public green spaces and that imposed strict COVID control measures to a smaller, lower density city with extensive suburbia and privately accessible green spaces, where COVID restrictions were comparatively less severe. We found out that despite the differences in climate, socioeconomics, history, and land-use (private-public access to green spaces), the availability, as well as the access to green and blue areas, was very highly valued among all respondents, thus supporting the notion that greening should be a fundamental strategy of cities when coping with a crisis, such as the COVID-19 pandemic. This overall result is supported by related research on values and perceptions of urban green spaces during the COVID-19 pandemic from other cities of the northern hemisphere, e.g., surveys conducted in China [1], Japan [20], European countries [2,3,23], and the USA [11]. However, the southern hemisphere still lacks research, except governmental releases in Australia [45] which also highlighted physical and mental health benefits from contact with nature during the pandemic. One of the Brisbane studies found a 7\% reduction in self-reported depression and a $9 \%$ reduction in high blood pressure of people visiting local parks. Australian researchers noticed that physical and mental health benefits from nature are particularly important for dwellers of high-density urban neighborhoods (e.g., apartment blocks) without access to green space [45].

Survey results revealed several negative impacts of COVID restrictions on people. First of all, lockdowns (restriction of movements and disruption of "normal" ways of life) and social distancing were the main negative impacts while working from home tended to be rated positively. Moreover, restrictions on socializing were particularly noticeable in Perth possibly due to the structure of neighborhoods (low density village-like small-town municipalities within the metropolitan city with private residential houses). People were isolated in their own homes reducing opportunities for physical socialization. Moscow, in contrast, is a megacity with densely-populated residential housing and an extremely crowded lifestyle. Here, socializing was reported as not so significant while "working from home" was rated significantly more positively in Moscow compared to Perth. Some respondents from Moscow indicated they had rethought their lifestyle and positively responded to working from home, thus avoiding busy public transport, traffic jams, and other stresses of urban city life.

However, respondents in both cities also indicated some positive outcomes of COVID19 restrictions. These included reduction of traffic on roads, reduced urban noise, cleaner air, more visible wildlife (Figure 5), and the opportunity to spend more time in green spaces. 
These results correspond with numerous media reports (Table 2) and published evidence from other cities around the globe $[45,46]$.

A comparison between Perth and Moscow indicated no significant relationship between the city variable and the importance of urban BGI on reported physical $(r=0.147)$ and mental well-being $(r=0.263)$ variables. In this case, the importance of urban BGI was not dependent on the city, its size, and climate conditions. However, the differences in restrictions have led to different results in Perth and Moscow on how people have coped with the COVID-19 challenges. Perth inhabitants had more opportunities to go outside and visit green and blue spaces $(72.7 \%)$. Additionally, many people have private gardens that allow them to have direct access to and contact with nature. However, in Moscow (where most public parks were officially closed) "take a walk outside" was among the leading activities (50.5\%, the second place after "doing physical exercises at home"), especially in a time when walking hours became restricted.

The greater importance of contact with nature for physical and mental well-being reported by Perth respondents, compared to Muscovites could be explained by Perth's climate conditions being more amenable for outdoor activities year-round and associated easier access to private and public green and blue areas $[8,28]$.

Respondent preferences to access different urban green and blue spaces indicated the significance of a nearby local park (pocket parks and gardens) during the pandemic and post-pandemic times. With the restriction of $100 \mathrm{~m}$, visitation of residential green spaces (as it was in Moscow) should be rethought and developed using new planning and design standards. The requirement of social distancing would also contribute to the spatial design of all public green spaces. However, it will be very difficult to achieve in the case of big cities where land is limited and expensive and where there is a constant conflict between different land users, e.g., between real-estate investors, powerful business organizations, and civil society/residents [6,47].

The preference for remnants of native vegetation (natural bushland) as a very desirable additional type of urban green and blue spaces in both cities $(60.5 \%$ in Perth and $42.4 \%$ in Moscow) illustrates the significance of such vegetation in the highly urbanized environment and need for contact with "native" nature for urban dwellers. Street plantings $(76.3 \%$ for Perth and $54.1 \%$ for Moscow) were also among the leading desirable types of urban green and blue spaces. This finding corresponds with an understanding of the role of green and blue spaces in mitigating the urban heat island effect and improving the urban environment also including the need for shady spaces-32.3\% for Perth and $48.6 \%$ for Moscow.

This research also revealed the importance of additional features/elements for urban BGI improvement. In both cases, people noticed a lack of benches as simple sitting places (38.4\% in Perth and 40.7\% in Moscow) which become one of the crucial elements of every urban park or garden space during the pandemic. Among other important elements were shelters for sun and rain (33.3\% in Perth and $42.1 \%$ in Moscow), which indicated the lack of strategic design and planning thinking at the moment and the necessity of the development of a new generation of garden furniture which provides comfort and security as well as allows for socializing.

The preference for new progressive ecological elements (e.g., green walls- $42.1 \%$ in Moscow and $12.1 \%$ in Perth, garden beds for urban farming and gardening-23.2\% in Perth and $12 \%$ in Moscow) in the list of additional types/elements of urban BGI indicated a growing public awareness for green and livable cities and the desire to have a more heterogeneous urban BGI which address current societal needs.

As the impacts of COVID-19 became increasingly prominent internationally, researchers worldwide contributed to a process of reflection focusing on the influence of both the physical form and use of the built and natural environment as part of societal reactions to the coronavirus $[2,18,19,21,26,46]$. Other studies $[4,18,46]$ along with the results of our survey, confirmed that some cities still lack appropriate levels of open green and blue spaces to meet the outdoor exercise and recreation demands of their citizens while fulfilling social distancing requirements. Within these scientific findings, significant atten- 
tion is centered on the mental and physical health impacts of COVID-19 and associated lockdowns as well as other restrictions $[3,48,49]$, and the specific role that urban nature played as a response [4,50]. In particular, it is stated that contact with nature can buffer or mitigate against the negative effects of social isolation on mental health $[3,26]$. Recent studies discussed urban BGI as a set of places, a set of amenities, and a set of processes and functions which were being planned for and how they could address COVID-19related challenges [21,51], suggesting that BGI networks which increase the openness and porosity of a city structure may produce future cities that are more resilient to viral pandemics [26,51]. In line with the results of other studies [4,18,19,25,49], our findings indicated that citizens need not only more green and blue spaces for different purposes and for different target social groups but also better access to them. Results of the survey in Perth and Moscow can contribute to understanding the variation in approaches to green and blue spaces planning and design. Our survey also revealed disparities in urban areas where access to nature is potentially more difficult or the quality of green and blue space is poor or does not correspond with the current societal needs. This moves beyond simple interpretations of urban planning policy as pro-economic development or pro-ecological resilience to a more nuanced appreciation of the decision-making process which addresses the needs of an urban diverse society. The COVID-19 pandemic has strengthened the call for the government to engage more effectively with this work. For example, several European countries have seen increased calls for additional funding from central and local governments to research urban BGI [18,21,24,25,48,51,52].

Much previous research has reported the positive effects of urban green space on human health and well-being. Nevertheless, discussions regarding the role of UGS under extremely stressful circumstances (such as during a pandemic) are limited [53-56]. Therefore, this paper has identified self-reported patterns of urban green and blue space visitation before, during, and after COVID-19 restrictions and the perceived associated health and well-being benefits for a sample of city residents and also allow residents to meet their social interaction needs during the pandemic period. Moreover, as indicated by the survey results, contact with nature is considered important for maintaining personal well-being, and therefore enabling access to urban BGI during the COVID-19 pandemic could mitigate the negative effects of lockdowns and subsequent social isolation on mental health and well-being. This relationship between urban green and blue space access and well-being during the pandemic is also supported by other studies $[20,26,57]$.

Some research indicates that the longer the quarantine period, the greater the negative impact on mental health and well-being [3,4], where people in quarantine have higher levels of avoidance behavior and anger. Simultaneously, the decrease in daily social behavior and interaction and physical contact with others can lead to depression and a sense of isolation [48,57-60]. In this regard, urban BGI can provide safe outdoor activities during city quarantines and can be a buffer zone to maintain good health and quality of life. Along with other authors $[18,23,24,57-60]$ we are of the view that promoting nature contact under the conditions of social distancing is an issue where suitable spatial organization and urban design could help maintain personal and community well-being during crises such as COVID-19.

It is clear that the urban planning pattern of the city and related typology of green spaces (dominancy of private gardens over public parks in Perth) demonstrates the benefits of having private green spaces and thus direct access to nature on an everyday basis even during a strict lockdown.

In our survey, people indicated some specific infrastructure elements such as benches shelters and which they thought will be beneficial to have in green spaces in time of the pandemic. This data can provide policymakers, designers, and planners with additional evidence and help to redesign and renovate open public spaces. For example, redesigning streets and public areas to free up space for pedestrians and recreationists as well as accessible open green space allowing social distancing can mitigate the negative effects of physical mobility restrictions as stated by other studies [26,51]. Specific suggestions of 
how different types of urban green spaces in Perth and Moscow should be designed and managed during isolation will need further professional landscape architecture research. One of the strategies to increase access to nature will be to have more greening in the courtyards, balconies, organizing green walls and green roofs, or have indoor plants during pandemics.

\section{Conclusions}

The survey results have shown that urban residents value and rely on the outdoor green and blue spaces to support their well-being, especially in the time of the COVID-19 pandemic. Survey data collected during the lockdown period has captured information about people's ability to access BGI, inequalities in access, feelings, and values as well as their opinions about desirable BGI elements which can create more comfortable public spaces during a pandemic. There is increasingly compelling evidence that access to BGI in urban areas is essential for human health.

The results demonstrate that respondents perceived the essential role of urban nature (in the form of green and blue spaces) for maintaining physical and mental well-being during times of crisis and in the post-pandemic world. Additionally, it indicates that access to nature and public rights to use greenspaces will be crucial for enhancing general urban resilience to crisis. This exploratory study provides the basis for further research on the success or failure of contemporary landscape design and planning approaches to urban green and blue areas and to see how effectively they can support daily life, especially in a time of crisis like that posed by COVID-19. This research could serve to better inform decision-makers, urban planners, and designers in their efforts to create resilient and livable cities promoting healthy lifestyles and habitats after the pandemic.

Author Contributions: Conceptualization, D.D., M.I. and M.H.; methodology, D.D., M.I., A.K. and M.H.; software, A.K. and M.H.; validation, A.K. and M.H.; formal analysis, D.D., M.I., A.K. and M.H.; investigation, D.D., M.I., M.H., A.K., E.D. and V.V.; resources, D.D., M.I. and M.H.; data curation, A.K. and D.D.; writing, original draft preparation, D.D., M.I., M.H. and A.K.; writing, review and editing, D.D., M.I., M.H. and A.K.; visualization, V.V., A.K. and D.D.; supervision, D.D.; project administration, D.D. and M.I.; funding acquisition, E.D., D.D., V.V. and M.I. All authors have read and agreed to the published version of the manuscript.

Funding: The research was supported in part by the Horizon 2020 Framework Programme of the European Union, research and innovation project "CONNECTING Nature-COproductioN with NaturE for City Transitioning, Innovation and Governance" (Grant Agreement No 730222) and by the German Academic Exchange Service (DAAD East-partnership) within the project on "Urban ecosystem services and their assessment: exchange of experiences between Germany and Russia" (2018-2021). The social survey in Moscow was supported by the Russian Science Foundation project №19-77-30012. Spatial analysis, mapping and paper preparation was supported by the RUDN University Strategic Academic Leadership Program.

Institutional Review Board Statement: Not applicable.

Informed Consent Statement: Not applicable.

Data Availability Statement: The data presented in this study are available on request from the corresponding author. The data are not publicly available due to privacy restrictions relating to the anonymous participation in the survey.

Acknowledgments: We thank the University of Western Australia and Murdoch University for providing some in-kind support for social surveys in Perth. We are also grateful to Peoples Friendship University of Russia (RUDN), Moscow for administrative and technical support, and to RUDN University Strategic Academic Leadership Program.

Conflicts of Interest: The authors declare no conflict of interest. The funders had no role in the design of the study; in the collection, analyses, or interpretation of data; in the writing of the manuscript, or in the decision to publish the results. 


\section{References}

1. Xie, J.; Luo, S.; Furuya, K.; Sun, D. Urban Parks as Green Buers During the-19 Pandemic. Sustainability 2020, 12, 6751. [CrossRef]

2. Ugolini, F.; Massetti, L.; Calaza-Martinez, P.; Cariñanos, P.; Dobbs, C.; Ostoic, S.K.; Marin, A.M.; Pearlmutter, D.; Saaroni, H.; Šaulienè, I.; et al. Effects of the COVID-19 pandemic on the use and perceptions of urban green space: An international exploratory study. Urban For. Urban Green 2020, 56, 126888. [CrossRef]

3. Pouso, S.; Borja, A.; Fleming, L.E.; Gómez-Baggethun, E.; White, M.P.; Uyarra, M.C. Contact with blue-green spaces during the COVID-19 pandemic lockdown beneficial for mental health. Sci. Total Environ. 2021, 756. [CrossRef]

4. Slater, S.J.; Christiana, R.W.; Gustat, J. Recommendations for Keeping Parks and Green Space Accessible for Mental and Physical Health During COVID-19 and Other Pandemics. Prev. Chronic Dis. 2020, 17, 200204. [CrossRef] [PubMed]

5. Ghofrani, Z.; Sposito, V.; Faggian, R. A comprehensive review of blue-green infrastructure concepts. Environ. Sustain. 2017, 6, 15-36. [CrossRef]

6. Dushkova, D.; Ignatieva, M.; Melnichuk, I. Urban Greening as a Response to Societal Challenges. Towards Biophilic Megacities (Case Studies of Saint Petersburg and Moscow, Russia). In Making Green Cities: Concepts, Challenges and Practice; Breuste, J., Artmann, M., Ioja, C., Qureshi, S., Eds.; Springer Nature: Cham, Switzerland, 2021; in press.

7. Hughes, M. Researching the links between parklands and health. In Wellness Tourism: A Destination Perspective; Voigt, C., Pforr, C., Eds.; Routledge: London, UK, 2014; pp. 147-160.

8. Ignatieva, M.; Haase, D.; Dushkova, D.; Haase, A. Lawns in Cities: From a Globalised Urban Green space phenomenon to Sustainable Nature-Based Solutions. Land 2020, 9, 73. [CrossRef]

9. Andersson, E.; Langemeyer, J.; Borgström, S.; McPhearson, T.; Haase, D.; Kronenberg, J.; Barton, D.N.; Davis, M.; Naumann, S.; Röschel, N.L.; et al. Enabling Green and Blue Infrastructure to Improve Contributions to Human Well-Being and Equity in Urban Systems. BioScience 2019, 69, 566-574. [CrossRef] [PubMed]

10. Andreucci, A.B.; Russo, A.; Olszewska-Guizzo, A. Designing Urban Green Blue Infrastructure for Mental Health and Elderly Wellbeing. Sustainability 2019, 11, 6425. [CrossRef]

11. Grima, N.; Corcoran, W.; Hill-James, C.; Langton, B.; Sommer, H.; Fisher, B. The importance of urban natural areas and urban ecosystem services during the COVID-19 pandemic. PLoS ONE 2020, 15, e0243344. [CrossRef] [PubMed]

12. Braubach, M.; Egorov, A.; Mudu, P.; Wolf, T.; Ward Thompson, C.; Martuzzi, M. Effects of Urban Green Space on Environmental Health, Equity and Resilience. In Nature-Based Solutions to Climate Change Adaptation in Urban Areas. Theory and Practice of Urban Sustainability Transitions; Kabisch, N., Korn, H., Stadler, J., Bonn, A., Eds.; Springer: Cham, Switzerland, 2017. [CrossRef]

13. Kabisch, N.; Haase, D. Urban nature benefits-Opportunities for improvement of health and well-being in times of global change. Who Newsl Hous. Health 2018, 29, 1-11.

14. Völker, S.; Kistemann, T. The impact of blue space on human health and well-being-Salutogenetic health effects of inland surface waters: A review. Int. J. Hyg. Environ. Health 2011, 214, 449-460. [CrossRef] [PubMed]

15. Lamond, J.; Everett, G. Sustainable Blue-Green Infrastructure: A social practice approach to understanding community preferences and stewardship. Landsc. Urban Plan 2019, 191, 103639. [CrossRef]

16. Mao, Q.; Wang, L.; Guo, Q.; Li, Y.; Liu, M.; Xu, G. Evaluating Cultural Ecosystem Services of Urban Residential Green Spaces From the Perspective of Residents' Satisfaction With Green Space. Front. Public Health 2020, 8, 226. [CrossRef]

17. Ode Sang, Å.; Knez, I.; Gunnarsson, B.; Hedblom, M. The effects of naturalness, gender, and age on how urban green space is perceived and used. Urban For. Urban Green. 2016, 18, 268-276. [CrossRef]

18. Barton, D.; Haase, D.; Mascarenhas, A.; Langemeyer, J.; Baro, F.; Kennedy, C.P.; Andersson, E.; McPhearson, T. Enabling Access to Greenspace during the Covid-19 Pandemic-Perspectives from Five Cities. Nat. Cities. 2020. Available online: https://www.thenatureofcities.com/2020/05/04/enabling-access-to-greenspace-during-the-covid-19-pandemicperspectives-from-five-cities / (accessed on 15 June 2020).

19. Finnsson, P.T. COVID19 Crisis Highlights the Need for Accessible and Productive Urban Green Spaces. Nordregio Magazine 2020. Issue "Postpandemic Regional Development". 2020. Available online: https://nordregio.org/nordregio-magazine/issues/postpandemic-regional-development/covid19-crisis-highlights-the-need-for-accessible-and-productive-urban-green-spaces / (accessed on 12 December 2020).

20. Uchiyama, Y.; Kohsaka, R. Access and Use of Green Areas during the COVID-19 Pandemic: Green Infrastructure Management in the "New Normal". Sustainability 2020, 12, 9842. [CrossRef]

21. Kleinschroth, F.; Kowarik, I. COVID-19 crisis demonstrates the urgent need for urban greenspaces. Front. Ecol. Environ. 2020, 18, 318-319. [CrossRef]

22. Rousseau, S.; Deschacht, N. Public Awareness of Nature and the Environment During the COVID-19 Crisis. Environ. Resour. Econ. 2020, 76, 1149-1159. [CrossRef] [PubMed]

23. Shoari, N.; Ezzati, M.; Baumgartner, J.; Malacarne, D.; Fecht, D. Accessibility and allocation of public parks and gardens in England and Wales: A COVID-19 social distancing perspective. PLoS ONE 2020, 15, e0241102. [CrossRef]

24. Lennon, M. Green space and the compact city: Planning issues for a "new normal". Cities Health 2020, 1-4. [CrossRef]

25. Kordshakeri, P.; Fazeli, E. How the COVID-19 pandemic highlights the lack of accessible public spaces in Tehran. Cities Health 2020, 1-3. [CrossRef]

26. Venter, Z.S.; Barton, D.N.; Gundersen, V.; Figari, H. Urban nature in a time of crisis: Recreational use of green space increases during the COVID-19 outbreak in Oslo, Norway. SocArXiv 2020. [CrossRef] 
27. Kennewell, C.; Shaw, B.J. Perth, Western Australia. Cities 2008, 25, 243-255. [CrossRef]

28. Jones, C.; Newsome, D. Perth (Australia) as one of the world's most liveable cities: A perspective on society, sustainability and environment. Int. J. Tour. Cities 2015, 1, 18-35. [CrossRef]

29. Myers, N.; Mittermeier, R.A.; Mittermeier, C.G.; da Fonseca, G.A.B.; Kent, J. Biodiversity hotspots for conservation priorities. Nature 2000, 403, 853-858. [CrossRef]

30. Crilley, G.; Weber, D.; Taplin, R. Predicting visitor satisfaction in parks: Comparing the value of personal benefit attainment and service levels in Kakadu National Park, Australia. Visit. Stud. 2012, 15, 217-237. [CrossRef]

31. Moyle, B.D.; Weiler, B. Revisiting the importance of visitation: Public perceptions of park benefits. Tour. Hosp. Res. 2017, 17, 91-105. [CrossRef]

32. Madureira, H.; Nunes, F.; Oliveira, J.; Madureira, T. Preferences for urban green space characteristics: A comparative study in three Portuguese cities. Environments 2018, 5, 23. [CrossRef]

33. Zhang, Y.; Van den Berg, A.E.; VanDijk, T.; Weitkamp, G. Quality over quantity: Contribution of urban green space to neighborhood satisfaction. Int. J. Environ. Res. Public Health 2017, 14, 535. [CrossRef]

34. Sobyanin Explained the Rules of Walking and Outdoor Sports; RIA Novosti. 27 May 2020. Available online: https://ria.ru/20 200527/1572086956.html?utm_source=yxnews\&utm_medium=desktop\&utm_referrer=https\%3A\%2F\%2Fyandex.ru\%2Fnews (accessed on 12 November 2020). (In Russian).

35. Coronavirus Restrictions Leave Gyms Facing Tough Recovery as Fitness Industry Looks for Silver Lining. 28 May 2020. Available online: https: / /www.abc.net.au/news / 2020-05-28/gyms-hit-hard-by-coronavirus-crisis-as-fitness-industry-adapts /12293978 (accessed on 20 October 2020).

36. Mental Disorders: What People Suffer after the Coronavirus. 4 August 2020. Available online: https://www.gazeta.ru/social/20 20/08/04/13177285.shtml (accessed on 12 November 2020).

37. WA Impact Statement: COVID-19 Pandemic. State of Western Australia 2020; Department of the Premier and Cabinet, Western Australia. Available online: https:/ / www.wa.gov.au/sites/default/files/2020-07/WA\%20Impact\%20Statement.pdf (accessed on 2 November 2020). (In Russian)

38. Coronavirus COVID-19 Monitor. Moskalkova Reported an Increase in Cases of Domestic Violence during the Epidemic. Available online: https:/ / coronavirus-monitor.ru/ru/novosti/moskalkova-soobshchila-o-roste-sluchaev-domashnego-nasiliyavo-vremya-epidemii (accessed on 4 November 2020). (In Russian).

39. Ministry of Transport of the Russian Federation. Transport of Russia. Information and Statistical Bulletin. January-June 2020. Available online: https:/ / www.mintrans.gov.ru/documents/7/10880 (accessed on 17 November 2020). (In Russian)

40. News. The Data Shows How the Coronavirus Shutdown Transformed Life in Australia's Most Isolated City. Available online: https:/ / www.abc.net.au/news/2020-04-26/life-in-perth-during-a-global-coronavirus-pandemic-in-photos/12174454 (accessed on 25 November 2020).

41. TASS. Mosekomonitoring Has Recorded a Decrease in Air Pollution in the Capital [Moscow]. Available online: https://tass.ru/ moskva/9115199 (accessed on 17 November 2020). (In Russian).

42. Australia's Science Channel. These 5 Images Show How Air Pollution Changed over Australia's Major Cities before and after Lockdown. Available online: https:/ / australiascience.tv/air-pollution-over-australian-cities-during-lockdown/ (accessed on 29 November 2020).

43. COVID-19 Mobility: Find out How People Move around the City in the Context of the COVID-19 Pandemic. Available online: https: / / www.google.com/covid19/mobility/?hl=ru (accessed on 3 December 2020). (In Russian).

44. ICLEI. Australians More Positive about Public Green Spaces. Available online: https://www.icleioceania.org/icleioceanianews/ 2020/8/12/covid-19-green-space\#: \{\}:text=In\%20April\%202020\%2C\%20Greener\%20Spaces,community $\% 20$ attitudes $\% 20$ towards\%20green \%20space (accessed on 20 December 2020).

45. Buckley, S. Green Spaces Help Soothe COVID-19 Restrictions. Available online: https:/ /www.architectureanddesign.com.au/ news / a-greener-covid-19\# (accessed on 18 March 2021).

46. Sharifi, A.; Khavarian-Garmsir, A.R. The COVID-19 pandemic: Impacts on cities and major lessons for urban planning, design, and management. Sci. Total Environ. 2020, 749, 142391. [CrossRef] [PubMed]

47. Kronenberg, J.; Haase, A.; Laszkiewicz, E.; Antal, A.; Baravikova, A.; Dushkova, D.; Filčak, R.; Haase, D.; Ignatieva, M.; Khmara, Y.; et al. Environmental justice in the context of urban green space availability, accessibility, and attractiveness in postsocialist cities. Cities 2020, 106, 102862. [CrossRef]

48. Ahmadpoor, N.; Shahab, S. Urban form: Realising the value of green space: A planners' perspective on the COVID-19 pandemic. Town Plan Rev 2021, 92, 49-55. [CrossRef]

49. Public Health England. Improving Access to Greenspace: A New Review for 2020; PHE Publications: London, UK, 2020; Available online: https:/ / beyondgreenspace.net/2020/07/29/improving-access-to-greenspace-a-new-review-for-2020/ (accessed on 8 January 2021).

50. Lopez, B.; Kennedy, C.; McPhearson, T. Parks are Critical Urban Infrastructure: Perception and Use of Urban Green Spaces in NYC During COVID-19. Preprints 2020. [CrossRef]

51. Honey-Roses, J.; Anguelovski, I.; Bohigas, J.; Chireh, V.K.; Daher, C.; van den Bosch, C.K.; Litt, J.; Mawani, V.; McCall, M.K.; Orellana, A.; et al. The Impact of COVID-19 on Public Space: A Review of the Emerging Questions. Preprints 2020. [CrossRef]

52. Pinheiro, M.D.; Luís, N.C. COVID-19 Could Leverage a Sustainable Built Environment. Sustainability 2020, 12, 5863. [CrossRef] 
53. Hanzl, M. Urban forms and green infrastructure-The implications for public health during the COVID-19 pandemic. Cities Health 2020. [CrossRef]

54. Otu, A.; Charles, C.H.; Yaya, S. Mental health and psychosocial well-being during the COVID-19 pandemic: The invisible elephant in the room. Int. J. Ment. Health Syst. 2020, 14, 38. [CrossRef]

55. Soga, M.; Evans, M.J.; Tsuchiya, K.; Fukano, Y. A room with a green view: The importance of nearby nature for mental health during the COVID-19 pandemic. Ecol. Appl. 2020, 31, e2248. [CrossRef]

56. Takieddine, H.; AL Tabbah, S. Coronavirus Pandemic: Coping with the Psychological Outcomes, Mental Changes, and the “New Normal" During and After COVID-19. Open J. Depress. Anxiety 2020, 2, 7-19. [CrossRef]

57. Samuelsson, K.; Barthel, S.; Colding, J.; Macassa, G.; Giusti, M. Urban nature as a source of resilience during social distancing amidst the coronavirus pandemic. Landsc. Urban Plan 2020. [CrossRef]

58. Cave, B.; Kim, J.; Viliani, F.; Harris, P. Applying an equity lens to urban policy measures for COVID-19 in four cities. Cities Health 2020. [CrossRef]

59. Geary, R.S.; Wheeler, B. A call to action: Improving urban green spaces to reduce health inequalities exacerbated by COVID-19. Prev. Med. 2021, 145. [CrossRef]

60. Reilly, K.; Van Ham, C.; Andersson, E. Green Refuges for Enabling Cities' Preparedness for Future Pandemics and Global Change; ENABLE Factsheet. 2020. Available online: https:/ / oppla.eu/sites/default/files/images/ENABLE_factsheet_Green_spaces_as_ pandemic_refuges.pdf?pk_campaign=Outline (accessed on 1 February 2021). 